\title{
25. BIOSTRATIGRAPHY
}

\section{CENOZOIC FORAMINIFERAL FAUNAS}

\author{
W. A. Berggren \\ Woods Hole Oceanographic Institution \\ Woods Hole, Massachusetts
}

A summary discussion is presented in this section of the biostratigraphic results obtained from an examination of the Cenozoic foraminiferal faunas in cores from the seven sites which were drilled and cored during the first leg of the Project. A general summary of the significant foraminiferal elements of the cores at each site is followed by a comparison between sites where pertinent. Separate discussions on average rates of sedimentation are presented, insofar as they have a bearing on estimated positions of geologic boundaries and correlation of biostratigraphic intervals between sites.
In assigning core intervals to planktonic foraminiferal zones in the late Cenozoic, the scheme proposed by Blow (1969) has been used. Reference should be made to this work for further details and definitions.

\section{The Gulf of Mexico Sites (1-3)}

\section{Paleontology}

Three sites were drilled by the Glomar Challenger in the Gulf of Mexico. These were, in order of their drilling: The Sigsbee Scarp Site (1), the Challenger Knoll (2), and the Sigsbee Abyssal Plain (3). In the following discussion these sites will be referred to by their number.

Site 1 was drilled to a total depth of 770.5 meters (2528 feet), and the entire section penetrated can be

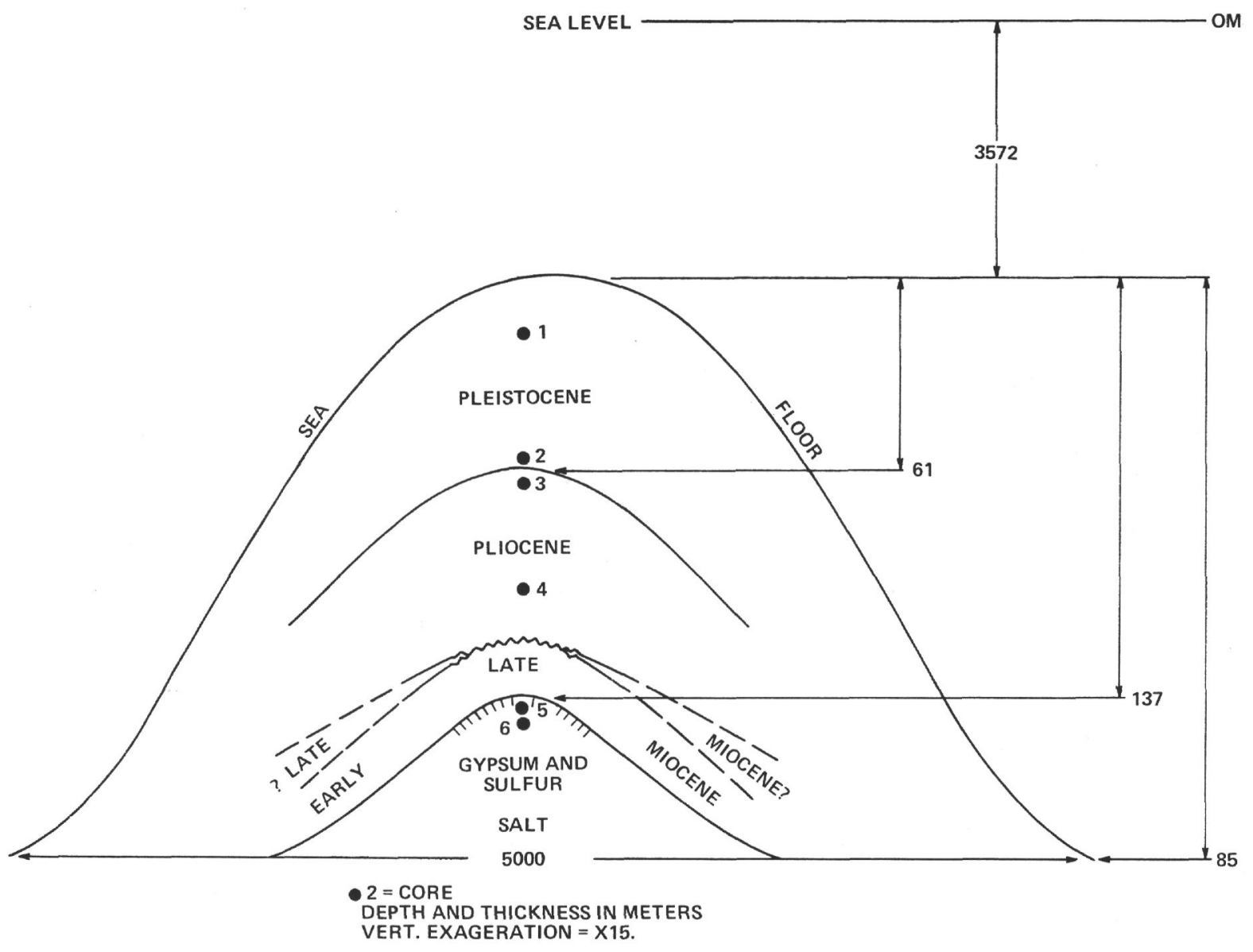

Figure 1. Schematic cross-section of Challenger Knoll. 
ascribed to the late Pleistocene-Holocene. The sediments are essentially silty and clayey turbidites which exhibit evidence of slumping and sliding. Planktonic foraminifera were found only within a few carbonate layers in the upper part of the hole (in Core 1). These faunas are essentially subtropical in nature, with abundant Globigerinoides rubra, G. sacculifera and Globorotalia menardii. Benthonic foraminifera of the genera Planulina, Cibicides, Gyroidina, Eponides, Bulimina, Bolivina, Uvigerina are associated with the planktonic faunas. In the turbidite layers various benthonic forms have been observed: buliminids, bolivinids, miliolids, nonionids, uvigerinids and several arenaceous genera, but these have been displaced and transported from shallower environments.

Site 2 was drilled to a depth of 144 meters (473 feet) below the sea floor. Six cores were taken of which the first four were fossiliferous; the lower two pierced petroliferous cap rock of the Challenger Knoll. Of the four fossiliferous cores, two are of Pleistocene age and two of Pliocene age.

The Pliocene-Pleistocene boundary has been determined at about 61 meters (201 feet), i.e., between the recovered intervals of Cores 2 and 3. Core 3 contains Globorotalia exilis and G. miocenica, which have been found to characterize the late Pliocene at Sites 2 and 3 in the Gulf of Mexico. Core 2 contains Globorotalia tosaensis and primitive forms of $G$. truncatulinoides. The first evolutionary appearance of Globorotalia truncatulinoides has been used by this writer to define the Pliocene-Pleistocene boundary in deep-sea cores based on its appearance near the base of the holostratotype section of the Calabrian at Santa Maria di Catanzaro in Calabria, Italy. An approximate age of 2 million years has been assigned to this datum-level and serves as a point of reference in placing the biostratigraphic sequence in a time framework (see below under discussion of rates of sedimentation). Paleomagnetic measurements on Cores 2 and 3 have yielded positive values, suggesting that the biostratigraphic boundary picked here is within the Olduvai Normal Event (see Opdyke \& Phillips, this volume, Chapter 23).

The lowest identifiable biostratigraphic level at Site 2 is within the lower part of Core 4 about 103 meters (338 feet), and is of mid-Pliocene age (i.e., within Zone N19). On the basis of the co-occurrence of Globorotalia tumida flexuosa (dextral) and Globorotalia margaritae, Core 4 has been estimated to lie within the interval of 3.36 and 3.7 million years ago (Hays et al., 1969; Saito, personal communication). A date of 3.5 million years ago has been chosen arbitrarily for the purpose of estimates of sedimentation rates (see below). Globorotalia crassula and G. multicamerata are distinctive elements in this core.

Site 3 was drilled to a total depth of 628 meters (2061 feet) below the sea floor. Of the 11 cores taken at this site, the first four were within the Pleistocene; Cores 3 and 4 are probably at or near the early late Pleistocene boundary (i.e., pre-glacial-glacial Pleistocene boundary). Cores 5 through 8 are within the Pliocene (Core 8 lies at or very near to the boundary between the Miocene and Pliocene); Cores 9 through 11 are within the late Miocene. The hole terminated at a level estimated on the basis of nannofossils to be of early late Miocene age.

Cores 1 and 2 are within the late Pleistocene and contain poorly sorted sands and silts with lignite and wood fibers, and a sparse and poorly preserved microfauna consisting predominantly of small benthonic forms, echinoid spines and sponge spicules. The sediments have been attributed to the action of turbidity currents from the region of the Mississippi Delta during the late Pleistocene glaciation of the North American Continent (see Chapter 24). Rich subtropical assemblages dominated by Globigerinoides rubra (including the pink variant), G. sacculifera, Globorotalia menardii and containing common to abundant Globorotalia truncatulinoides, Globoquadrina dutertrei (with well-developed apertural "teeth"). Pulleniatina obliquiloculata and Sphaeroidinella dehiscens characterize Cores 3 and 4 which were taken in a carbonate lutite sequence. The base of the turbidite sequence has been estimated to occur at approximately 197 meters (647 feet) in this hole (see Chapter 3 ), and an age of 0.7 million years ago has been used by this writer in estimating rates of sedimentation (see below).

A late Pliocene planktonic foraminiferal fauna occurs in Core 5. The two globorotaliid species, G. exilis and G. miocenica, characterize this core. However, data from Core 6 have allowed a more accurate determination of the position of these two cores within the late Pliocene. Globorotalia multicamerata and Globoquadrina altispira were found at the bottom of Core 6 at 333 meters (1093 feet). Neither were found above this level in Core 6, but both are common in Core 7 below; G. altispira is a common form in the early Pliocene (Core 8) and late Miocene (Core 9) in this hole as well. The extinction of Globoquadrina altispira in tropical Pacific cores has been found to occur at a level dated at 2.8 million years ago (Saito in Hays et al., 1969; Saito, personal communication). The association of planktonic foraminifera in Cores 5 and 6 suggests a biostratigraphic level within the late Pliocene. The absence of Sphaeroidinellopsis seminulina and S. subdehiscens, both of which became extinct about 2.9 million years ago (Saito in Hays et al., 1969; Saito, personal communication) in Core 6, and their presence together in Core 7, some 50 meters (165 feet) below Core 6although negative evidence-does support the suggestion that the absence of G. altispira, as well as $G$. multicamerata, at higher levels in Core 6 is due to extinction rather than to local, temporary disappearance for ecologic reasons. This level is within the biostratigraphic interval of the Globorotalia tosaensis Zone (N21), the 
base of which occurs at approximately 3 million years ago. Seven paleomagnetic measurements have been made on Cores 5 and 6, 320 meters (1050 feet) to 331.6 meters (1088 feet). All, save one, a reversal at 324.7 meters (1065 feet) in Core 5, are positive. The temptation is strong to identify this reversal as the Kaena Event which has been dated at about 2.8 million years.

The planktonic foraminferal fauna in Core 7 exhibits some differences from Core 6. In addition to the normal complement of species of Globigerinoides and Globoquadrina the following elements are of biostratigraphic importance: 1) Globorotalia multicamerata is a common form; 2) G. miocenica is present although it shows some differences with forms above in Cores 5 and 6: Specimens are generally more oval-elongate than circular in outline, and the test is very low-conical on the umbilical side; 3 ) robust, thick-walled specimens of dextrally coiled Globorotalia tumida s.1. (including G. tumida flexuosa) occur in two samples examined from Section 4, but are not found in the other three sections of this core. This, together with the occurrence of the characteristic Globorotalia crassula, suggests that Core 7 may lie at a stratigraphic level slightly higher than Core 4 at Site 2. The presence of abundant pyrite in the core catcher sample in Core 7 may be related to its presence in Core 4 at Site 2 as well.

Core 8 was taken at a depth of 429.5 meters (1409 feet) on the basis of estimated prediction of where the Miocene-Pliocene boundary should lie based upon estimated rates of sedimentation calculations. The fauna in Core 8 suggests, indeed, as predicted, a level very close to the Miocene and Pliocene boundary. The presence of Sphaeroidinellopsis subdehiscens, S. seminulina, Sphaeroidinella dehiscens s.l. (including $S$. dehiscens

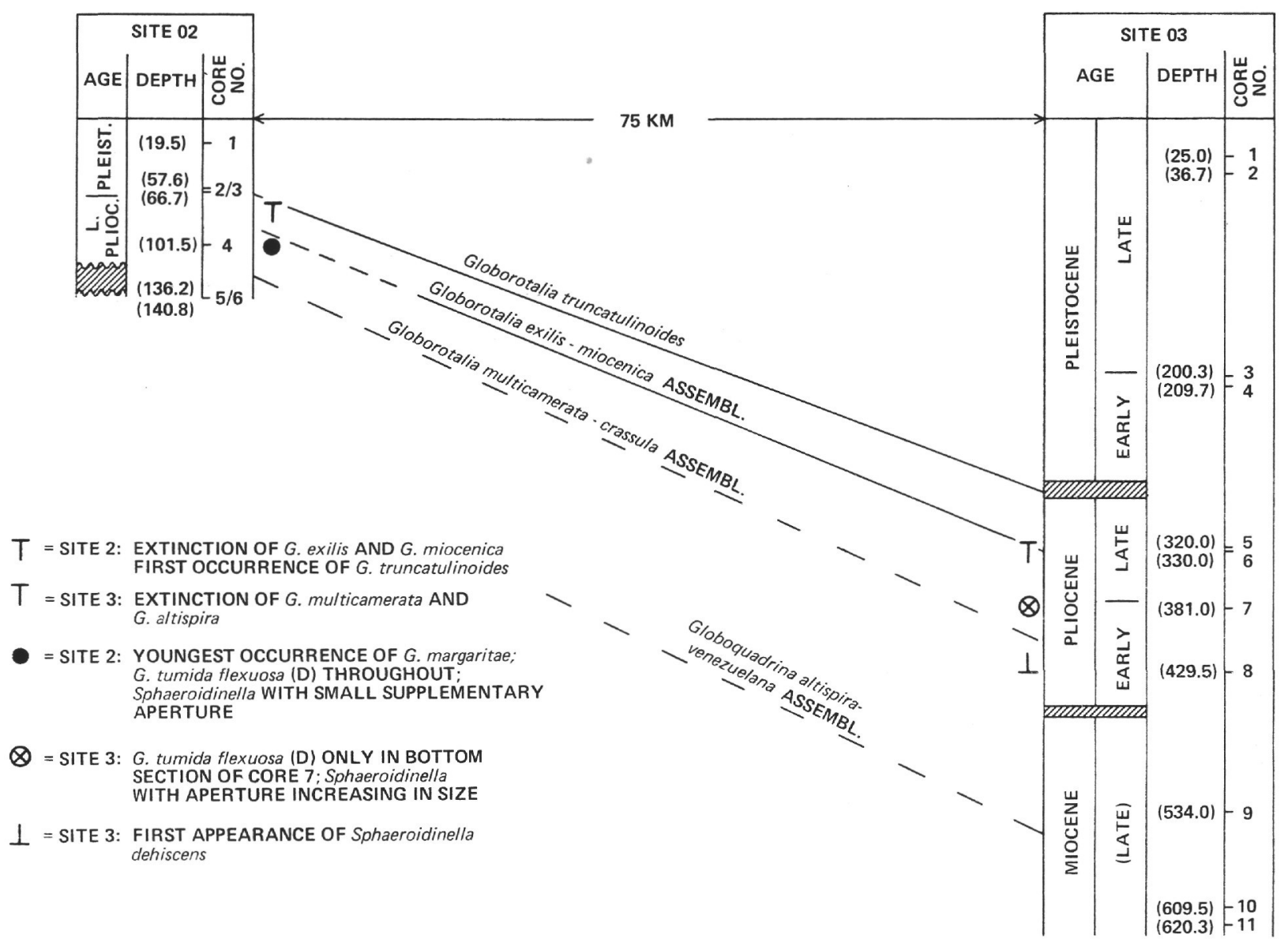

Figure 2. Generalized Biostratigraphic Correlation Between Sites 2 and 3 based on Planktonic Foraminiferal Assemblages. 
f. immatura)-with extremely small supplenıentary aperture on the spiral side-and Globorotalia praehirsuta indicate a stratigraphic level near the base of Zone N19 (see discussion by Bukry and Bramlette on evidence of nannofossils).

The dominant planktonic foraminifera in Core 9 are: Globoquadrina altispira, G. venezuelana and Sphaeroidinellopsis subdehiscens. Globigerina nepenthes is also present in minor quantities. The presence of Globigerinoides canimurensis indicates that this core occurs within a biostratigraphic interval, which is at least post-Zone N16 (Tortonian). Evidence from the nannofossils suggests that this core can be placed within the Messinian Stage. On the basis of sedimentation rate calculations described below, this core is estimated to lie at a stratigraphic level which is between 8 and 9 million years old, and which is approximately correlative to the boundary between Zones N18 and N19.

The planktonic foraminiferal fauna in Core 10 is too poor to allow accurate biostratigraphic determination.

\section{Estimated Rates of Sedimentation}

In the following discussion, the assumption is made that sedimentation was essentially continuous at Sites 2 and 3. At Site 2, atop the Challenger Knoll, the cored sediments give the appearance of having been deposited under stable conditions and with a minimum of postdepositional disturbance. However, an unconformity is postulated between Cores 4 and 5 , and this will be discussed in the section on stratigraphic correlation. At Site 3 , there is evidence of significant turbidity deposition in Cores 1 and 2 (which is probably related to excess load discharge from the Mississippi Delta during late Pleistocene glaciation on the continent of North America). In the Pliocene, there is evidence of turbidity current deposition in the form of intercalated carbonate turbidites and pelagic lutites. The source of these Pliocene turbidites was probably the Campeche Banks of Mexico to the south (see discussion by Fischer, this volume). The planktonic foraminiferal faunas do not suggest significant reworking by these turbidites, i.e., stripping of older beds on the sea floor, but rather penecontemporaneous transportation and redeposition. In the late Miocene, a thick sequence of lignitic silts and clays has masked the accumulation of planktonic foraminifera and their use in biostratigraphic determination is correspondingly reduced. Thus, the estimates made here should be viewed as only approximations; and, in addition, they should be viewed as representing average rates of sedimentation. On the other hand, the estimates presented here have allowed approximate stratigraphic correlation between Sites 2 and 3 and they place, within a time framework, the geologic processes which have occurred at these two sites.

At Site 2 (Challenger Knoll), the Pliocene-Pleistocene boundary has been biostratigraphically determined at
61 meters (200 feet). On the basis of age determination of 2 million years ago for this level, an average rate of sedimentation of $3 \mathrm{~cm} / 1000$ years is obtained (Figure 3). On the basis of the occurrence of dextrally coiling Globorotalia tumida flexuosa and G. margaritae in Core 4, an age of 3.36 to 3.7 million years has been estimated for a level at about 100 meters (328 feet). In view of the fact that Globigerina nepenthes, which became extinct about 3.7 million years ago, does not occur in Core 4, an estimate midway between these two values is suggested here: 3.5 million years. On this basis an estimated rate of sedimentation of $2.6 \mathrm{~cm} / 1000$ years is obtained for the late Pliocene at Site 2 (Figure 3).

Evidence of early late Miocene was found in the stratigraphic interval above the top of the cap rock of the Challenger Knoll (Bukry and Bramlette, this section). This level (which is probably just above the top of the cap rock) has been determined as being slightly older than the oldest level encountered at Site 3. An unconformity is postulated above the cap rock of this knoll; this is discussed more fully in the section on stratigraphic correlation below.

By extrapolating upwards from the base of the Pleistocene at about 61 meters (200 feet) and using the same sedimentation rate $(3 \mathrm{~cm} / 1000$ years $)$, Core 1 would lie at a level which is approximately 0.7 million years or near the base of the glacial Pleistocene, i.e., boundary between early and late Pleistocene. It is more likely that rates of sedimentation were slightly higher during the late Pleistocene, and slightly lower during the early Pleistocene at this site. If this is true, Core 1 would lie somewhat higher in the late Pleistocene, i.e., younger than 0.7 million years ago, and within the Brunhes Normal Event. Paleomagnetic measurements which have been made upon Core 1 have yielded positive, i.e., normal, values which suggest that this core is, indeed, within the Brunhes Normal Event.

At Site 3, conditions are somewhat more complicated. The determination of significant stratigraphic boundaries is based on estimated rates of sedimentation, which are in turn based upon age determination of various biostratigraphic levels. The intercalation of thin carbonate turbidites has served to "stretch out" the section in the Pliocene considerably.

The boundary between the terrigenous detrital turbidites of the late Pleistocene and the foraminiferal-coccolith lutites of the early Pleistocene has been estimated to lie at about 197 meters (646 feet) at Site 3. If this determination and the age assignment of 0.7 million years ago for this boundary are correct, an average sedimentation rate of $28 \mathrm{~cm} / 1000$ years is obtained for the late (glacial) Pleistocene at this site.

A level at 333 meters (1082 feet) at Site 3 has been determined as being about 2.8 million years old on the 


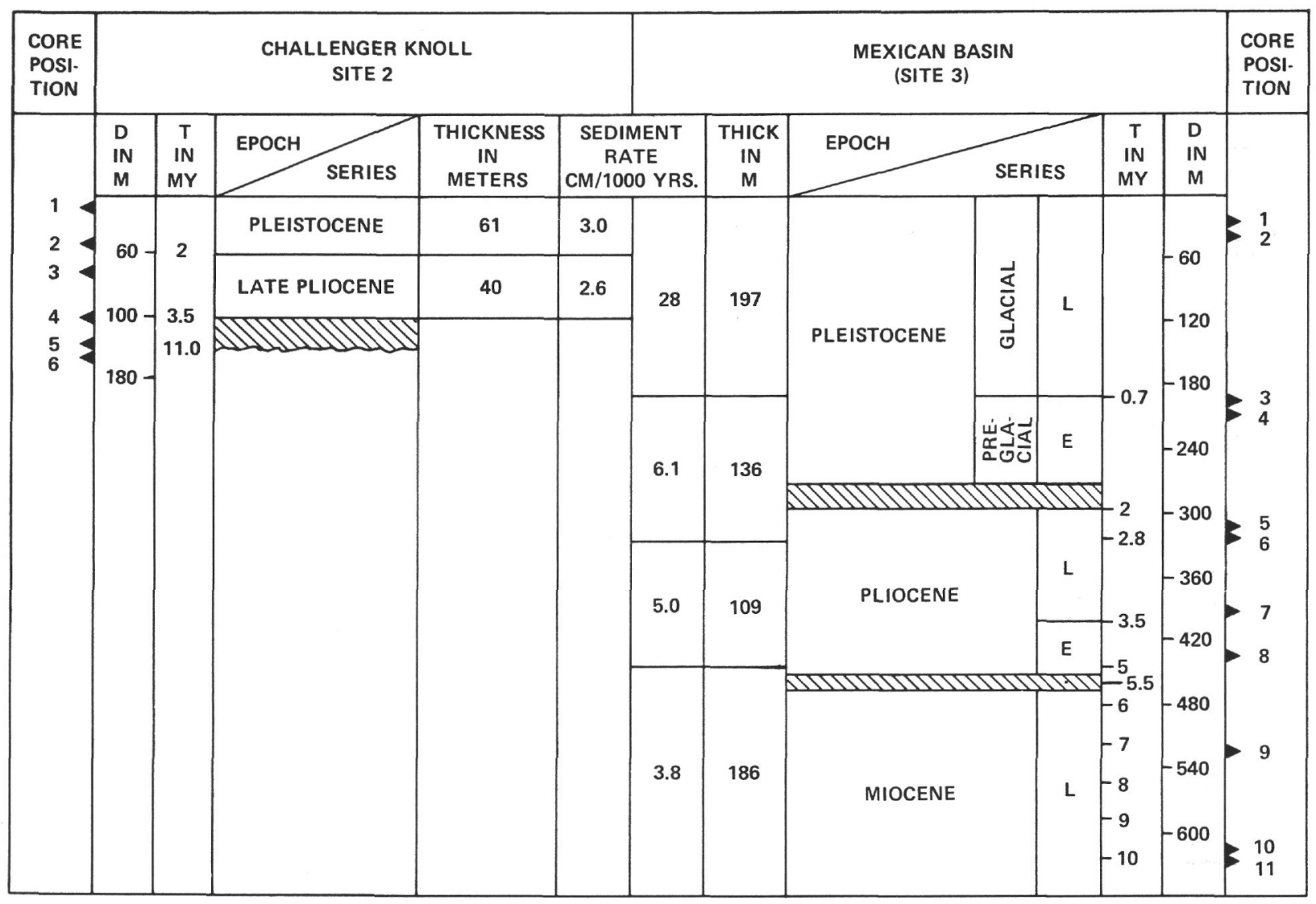

Figure 3. Comparison of late Cenozoic sediment thickness and estimated rates of sedimentation: Challenger Knoll and Mexican Basin ( $D$ in $m=$ depth in meters; $T$ in m.y. = time in million years).

basis of the extinction of Globorotalia multicamerata and Globoquadrina altispira. This level is within the late Pliocene. If this level within the late Pliocene and that above at the early-late Pleistocene boundary at 197 meters (646 feet) is used, an average sedimentation rate of $6.1 \mathrm{~cm} / 1000$ years for the late Plioceneearly Pleistocene (Figure 3 ) is obtained.

The base of Core 8 at 438 meters ( 1437 feet) lies at or near the base of Zone N19 and is estimated here to be about 5 million years old. On the basis of this estimate, an average sedimentation rate of $5.0 \mathrm{~cm} / 1000$ years is obtained for the stratigraphic interval between the base of Core 8 and the base of Core 6 , i.e., essentially the early Pliocene.

In this connection it is of interest to observe that the estimate average rate of sedimentation in the Pliocene at Site 2 is about $2.6 \mathrm{~cm} / 1000$ years; and at Site 3 it is about $5.6 \mathrm{~cm} / 1000$ years, approximately twice that at
Site 2. Confirmation that this difference is real was obtained when a count of turbidite and non-turbidite layers in a Pliocene core at Site 3 revealed that the turbidite layers accounted for approximately 50 per cent of the measured stratigraphic thickness.

An age of about 10 million years ago had been estimated for the base of the stratigraphic section (Core 11) at Site 3. This level has been determined by Bukry and Bramlette (see report, this section) to be within the Tortonian, but somewhat younger than the oldest biostratigraphic level from which nannofossils were obtained above the Challenger Knoll. An average rate of sedimentation of $3.8 \mathrm{~cm} / 1000$ years is obtained for the late Miocene lignitic sands and clays at Site 3 (Figure 3).

\section{Stratigraphic Correlation}

Stratigraphic correlation between Sites 2 and 3 can be achieved by a combination of comparison of faunal elements (biostratigraphic approach) and estimated 
absolute dates on various biostratigraphic levels or datum points (time-stratigraphic approach). The recognition and determination of the major geologic boundaries (stages or epochs) is of primary importance in biostratigraphy, for if a relatively accurate "absolute" date is available for these boundaries, it is then possible to place within a time framework, the subsequent observations and calculations made within a given stratigraphic interval.

At Site 2, the main determinations which have been made include: the Pliocene-Pleistocene at 61 meters (220 feet); age, ca. 2 million years ago; a level within the early Pliocene at about 100 meters (328 feet); age, ca. 3.5 million years ago. At Site 3 , the main determinations include: a level at 333 meters (1082 feet) in the late Pliocene, age $c a$. 2.8 million years ago; a level at 438 meters (1437 feet) near the base of Zone N19; age, $c a$. 5 million years ago; a level at 628 meters (2060 feet) in the Tortonian, age, ca. 10 million years ago.

Since the Pliocene-Pleistocene boundary was not cored at Site 3, its position can only be estimated based upon estimated average rates of sedimentation. If the rate which was obtained for the early late Pliocene of
$5.0 \mathrm{~cm} / 1000$ years is used, its position would lie at about 292 meters (958 feet). Thus, the PliocenePleistocene boundary at Site 3 is estimated to lie between 283 meters (928 feet) and 292 meters (958 feet), and this level is correlated with 61 meters (200 feet) at Site 3 (Figures 3-5).

A combination of faunal elements has been used in subdividing the Pliocene at Site 3 and in achieving stratigraphic correlation with Site 2. These include: successive associations of globorotaliid species; globoquadrinid species, and the development of the genus Sphaeroidinella. The late Pliocene has been cored at Sites 2 and 3, the uppermost part in Core 3 at Site 2, and a lower stratigraphic level in Cores 5 and 6 at Site 3. The base of Core 6 at Site 3 has been dated at about 2.8 million years ago, which is slightly above the biostratigraphic base of the Globorotalia tosaensis Zone N21. At both sites, a late Pliocene fauna is characterized by the abundant co-occurrence of Globorotalia miocenica and $G$. exilis. In broad terms, the late Pliocene at these two sites could be said to be characterized by a Globorotalia miocenica and G. exilis assemblage (see Figure 5).

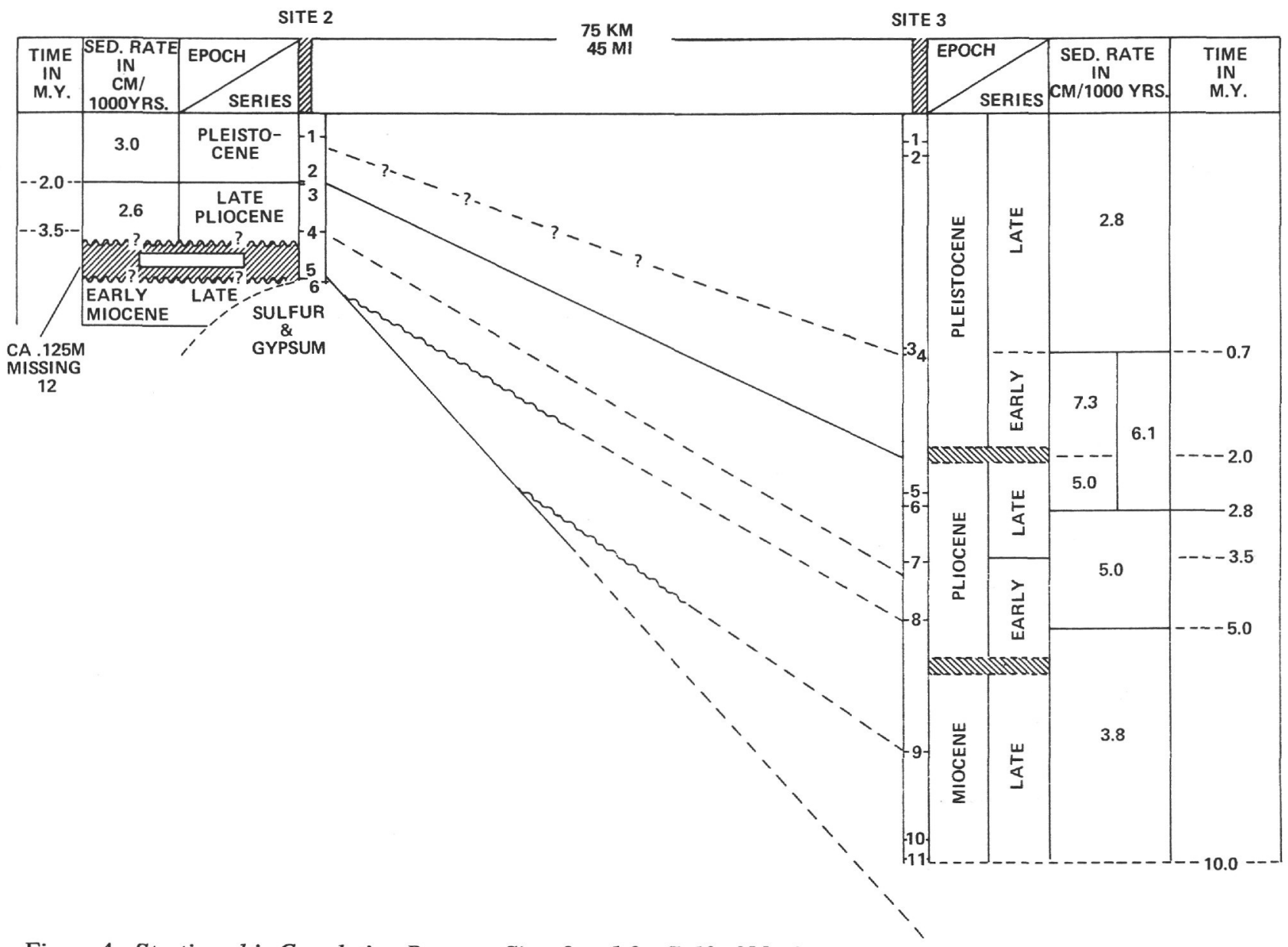

Figure 4. Stratigraphic Correlation Between Sites 2 and 3: Gulf of Mexico. 


\begin{tabular}{|c|c|c|c|c|c|c|}
\hline \multicolumn{2}{|c|}{ EPOCH SERIES } & \multirow{2}{*}{$\begin{array}{c}1 \\
<770.5 \mathrm{~m}\end{array}$} & \multirow{3}{*}{$\begin{array}{c}2 \\
61 \mathrm{~m}\end{array}$} & \multicolumn{2}{|c|}{3} & $\begin{array}{c}\text { TIME } \\
\text { IN }\end{array}$ \\
\hline \multirow{2}{*}{ PLEISTOCENE } & LATE & & & \multirow{2}{*}{$285 \mathrm{~m}$} & $197 \mathrm{~m}$ & \multirow{2}{*}{0.7} \\
\hline & EARLY & & & & $76 \mathrm{~m}$ & \\
\hline \multirow{2}{*}{ PLIOCENE } & LATE & & $40 \mathrm{~m}$ & \multirow{2}{*}{$157 \mathrm{~m}$} & $69 m$ & \multirow{2}{*}{3.5} \\
\hline & EARLY & & & & $88 \mathrm{~m}$ & \\
\hline \multirow[t]{2}{*}{ MIOCENE } & LATE & & & \multirow[t]{2}{*}{ - } & $186 \mathrm{~m}$ & \multirow[b]{2}{*}{10} \\
\hline & & & $? ?$ & & & \\
\hline
\end{tabular}

Figure 5. Comparison of sediment thickness in Gulf of Mexico. 1. Sigsbee Escarpment $\left(25^{\circ} 51.5^{\prime} \mathrm{N} ; 92^{\circ} 11.0^{\prime}\right.$ W). 2. Challenger Knoll $\left(23^{\circ} 27.3^{\prime} N ; 92^{\circ} 35.2^{\prime} \mathrm{W}\right)$. 3. Sigsbee Abyssal Plain $\left(23^{\circ} 01.8^{\prime} N ; 92^{\circ} 02.6^{\prime} \mathrm{W}\right)$.

The position of Core 7 at Site 3 is of importance in correlation between Sites 2 and 3 within the late early Pliocene. An association of dextrally coiled Globorotalia tumida flexuosa, G. multicamerata, G. crassula, Globoquadrina altispira and Sphaeroidinella dehiscens (with small supplementary aperture) characterizes Core 4 at Site 2. In addition, Globorotalia margaritae has been found in this core. An age of $c a$. 3.5 million years ago has been estimated for this core at about 100 meters (328 feet). Core 7 at Site 3 contains an assemblage of Globorotalia multicamerata, G. crassula, Globoquadrina altispira and Sphaeroidinella dehiscens (with small supplementary aperture) throughout. However, typical robust specimens of Globorotalia tumida flexuosa occur only in the bottom Section 4 of Core 3 .

The question is whether Core 7 at Site 3 is stratigraphically older or younger than Core 4 at Site 2 . There are several methods of approach. If Core 7 is of the same age, or somewhat older than Core 4 (i.e., greater than 3.5 million years ago) one might expect to find Globigerina nepenthes, which became extinct at 3.7 million years ago, present in the core. $G$. nepenthes does not occur above Core 8 at Site 3, however, and it does not occur in Core 4 at Site 2 either. Both cores would appear to be above its level of extinction. Within Core 7 at Site 3, somewhat atypical specimens of Globorotalia miocenica are not uncommon; they are low conical and generally have a somewhat oval-elongate outline rather than the circular outline typical of the species. In Core 6, above, G. miocenica becomes abundant and distinctive just above the level of extinction of Globorotalia multicamerata and Globoquadrina altispira at the bottom of the core. In Core 4 at Site 2, on the other hand, only rare specimens of rather small, atypical G. miocenica are found. This suggests that this level may lie somewhat lower stratigraphically than Core 7 at Site 3 in which $G$. miocenica-although atypical-is more common and somewhat better developed. The absence of Globorotalia margaritae in Core 7 at Site 3 also suggests it may lie above Core 4 at Site 2. G. margaritae, however, is extremely rare in Core 4 at Site 2, and its absence in Core 7 at Site 3 cannot be considered as definitive.

The development of the supplementary aperture and the extension of the periumbilical flange in Sphaeroidinella dehiscens to the morphologic expression which it exhibits in present day seas, occurred at about 3.0 million years ago (Saito, personal communication). At the base of the Pliocene, the transition from forms having no supplementary aperture, to those having a discrete opening with minute bordering apertural lip, can be observed. It occurs in Core 8 at Site 3 for instance (see Plates $1 \& 2$ ). Between the base of the Pliocene and 3.0 million years, the supplementary aperture gradually opens and expands in size. The transition from relatively small aperture, to wide, expansive aperture with the thick flange occurs relatively rapidly, however, just prior to 3.0 million years ago. In Core 4 at Site 2, all specimens of Sphaeroidinella dehiscens have a consistently small supplementary aperture: marginal flange is not developed. In Core 7 at Site 3 , a gradual transition can be observed in the development of the supplementary aperture in $S$. dehiscens. In the lower part of the core, specimens have a uniformly small supplementary aperture: towards the top of the core some specimens have a somewhat larger supplementary aperture and the rudimentary development of a marginal flange. This condition appears to be intermediate between the consistently small supplementary aperture in forms in the early Pliocene (Zone N19), and the large, excavated supplementary aperture and marginal flange which develops in the late Pliocene (Zone N21). This transition would appear to occur within Zone 20 interval. The presence in Core 7 at Site 3 of Globoquadrina pseudopima in relatively high numbers suggests that this core is within Zone N20. G. pseudopima was not found in Core 4 at Site 2. This would also suggest that Core 7 at Site 3 is stratigraphically younger than Core 4 at Site 2. Finally, if we apply the approach of using average rate of sedimentation $(5.0 \mathrm{~cm} / 1000$ years; see discussion above and Figure 4) Core 7, a level at approximately 385 meters (1263 feet), would have an age of about 3.8 million years ago. This would place it somewhat older than the estimated age of Core 4 at Site 2.

Paleomagnetic measurements which have been made upon Core 7 may have a bearing on the problem of the age of this core and its stratigraphic relationship to Core 4 at Site 2. Four measurements have been made (see Opdyke and Phillips, this volume), one on each of the four sections. These are (from top to bottom):

Core 7, Section $1-381.3 \mathrm{~m}$ : reversed

Core 7, Section $2-382.5 \mathrm{~m}$ : normal

Core 7, Section 3 - $384.7 \mathrm{~m}$ : normal

Core 7, Section $4-386.8 \mathrm{~m}$ : reversed According to Phillips (personal communication), the measurement made on Section 1 is not wholly reliable due to low inclination: The other three appear to be reliable. It would seem that two interpretations are 

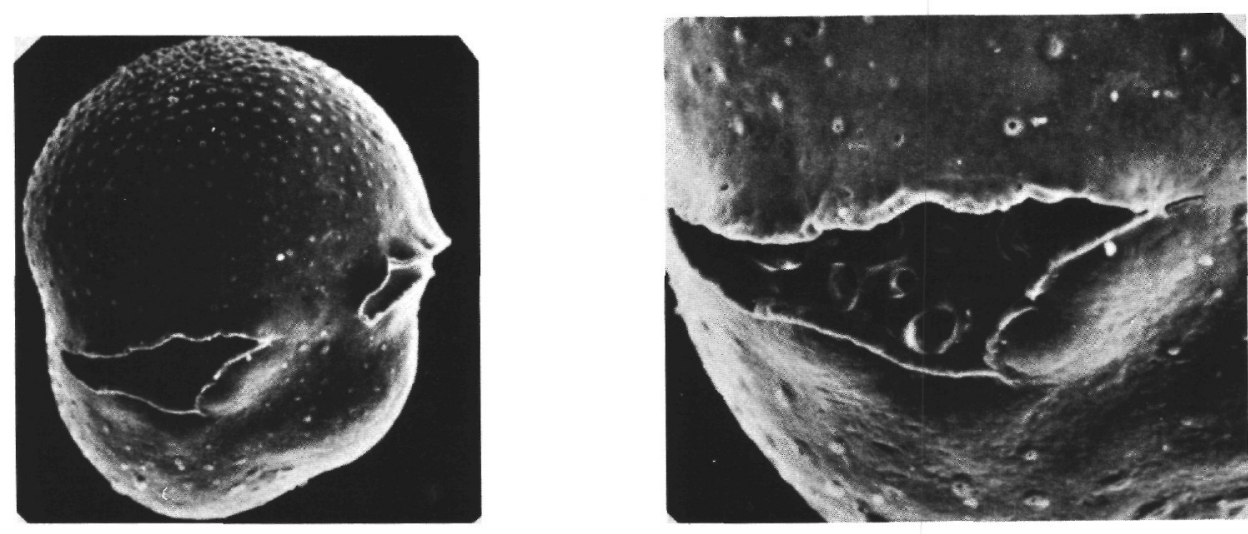

LATE PLIOCENE

$1 / 3 / 6 / 1$

TOP
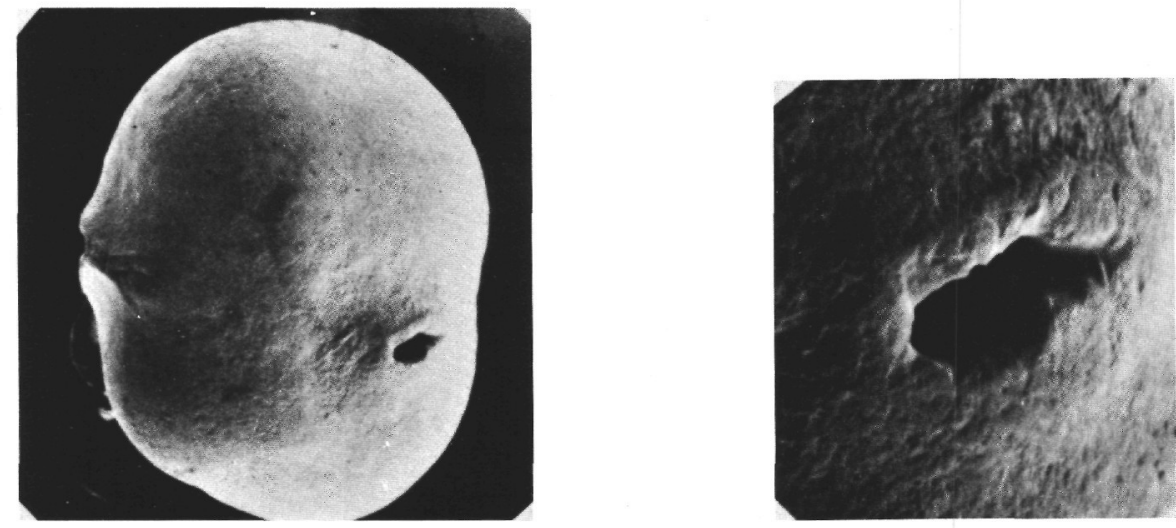

\section{EARLY MIDDLE PLIOCENE}

$1 / 3 / 7 / 1$

$4-5 \mathrm{~cm}$

Plate 1. Evolutionary development of Sphaeroidinella dehiscens. 


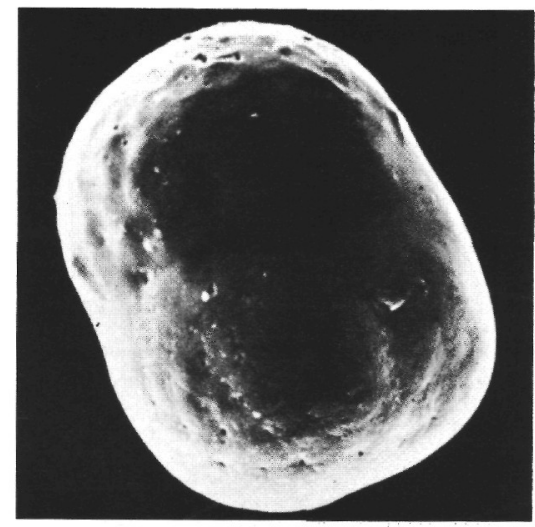

EARLY (BASAL) PLIOCENE $1 / 3 / 8 / 6$

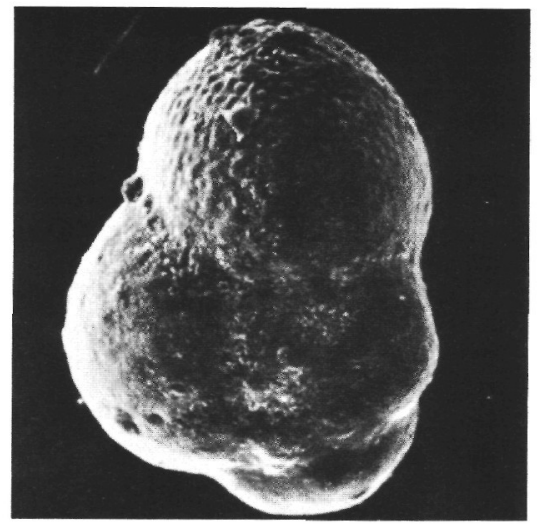

LATE MIOCENE $1 / 3 / 9 / 7$

cC

Plate 2. Evolutionary development of Sphaeroidinella dehiscens. 

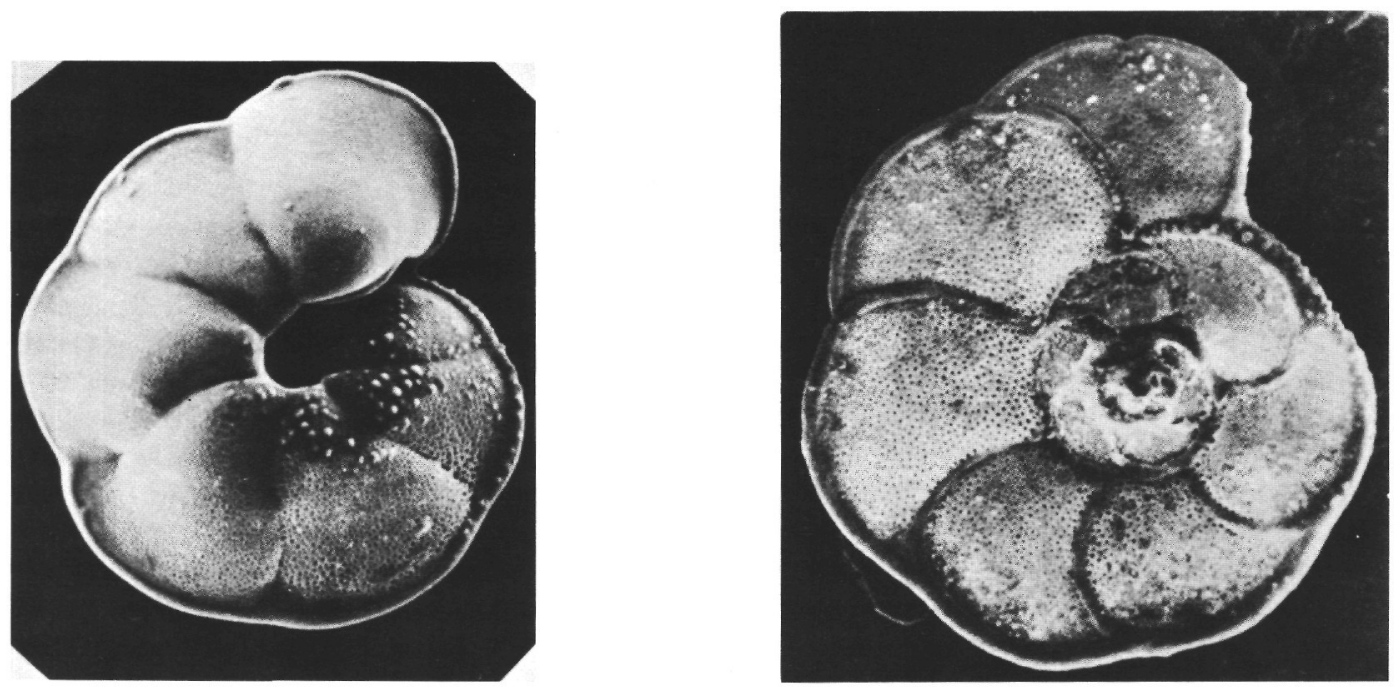

$3 A$

$1 / 2 / 3 / 3$

cc
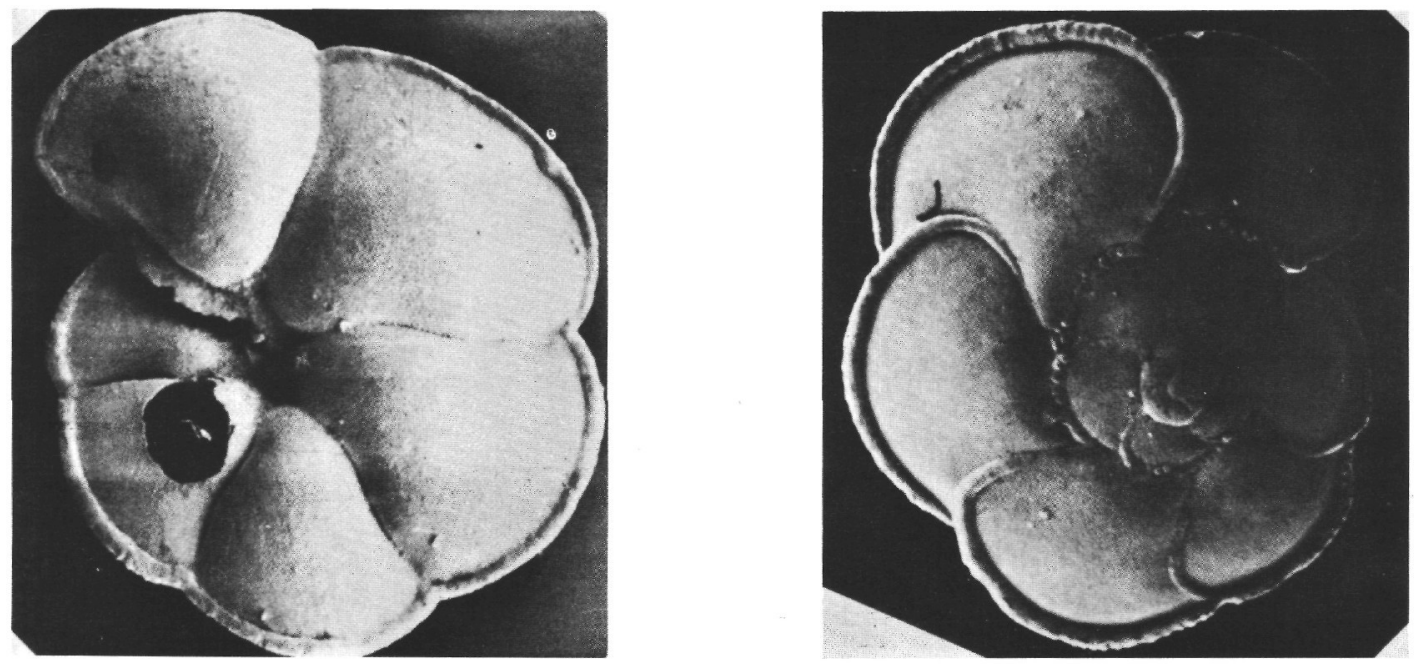

$3 B$

Plate 3. Late Pliocene Globorotalids from Site 2. (3A) Globorotalia miocenica; (3B) Globorotalia cultrata exilis 
possible in the light of the biostratigraphic data summarized above: Core 7 at Site 3 may contain the boundary between the Gauss Normal and the Gilbert Reversed which is dated at 3.36 million years ago; alternatively, Core 7 may contain the lower boundary of Gilbert a, which is slightly older than 3.7 million years. The shift to dextral coiling in Globorotalia tumida flexuosa occurred at about 3.7 million years ago and the species is present only in the lower part of Core 7. Globigerina nepenthes became extinct at 3.7 million years ago and it is not present in Core 7 . The general appearance of the globorotaliid fauna indicates closer affinities with Core 6 above than with Core 4 at Site 2. Because of these observations, this writer would suggest that Core 7 is slightly younger than Core 4 at Site 2 i.e., about 3.3 to 3.4 million years old.

Thus, it would appear that the age estimate based upon average rates of sedimentation may be incorrect (that is, too old). The conclusion which follows is that average rates of sedimentation were higher between Cores 7 and 6 (mid-Pliocene), than between Cores 8 and 7 (early Pliocene).

The common element in Core 4 at Site 2 and Core 7 at Site 3 is the distinct association of Globorotalia crassula and G. multicamerata, (see Figure 5). This association may prove to be of regional biostratigraphic value in mid-Pliocene in the Gulf of Mexico. It may correspond to the Globorotalia aemiliana $(=G$. crotonensis $=G$. crassula) Zone which was recently suggested as definitive of the mid-Pliocene in the Mediterranean Region by a group of specialists on Mediterranean planktonic foraminiferal biostratigraphy.

The first appearance of a supplementary suture on the spiral side of the test has been used as the main biocharacter distinquishing the genus Sphaeroidinella from Sphaeroidinellopsis. This transition has been observed by Blow (personal communication) to occur approximately 12 meters (40 feet) above the base of the Zanclian (early Pliocene) in Sicily, and is used by him in distinquishing between his Zones N18 and N19. The lowest level at which forms with the discrete supplementary aperture have been observed, has been dated at 5.0 million years (Saito, personal communication). Forms with a discrete supplementary aperture occur throughout Core 8 at Site 3. They are extremely small; nevertheless, they are distinct, and some forms bear the distinct marginal lip over the opening which serves to distinguish the true opening as a morphocharacter from a crack which may be due to solution effects. The base of Core 8 at Site 3 is thus assigned an approximate age of 5.0 million years ago and considered to lie very near the Miocene-Pliocene boundary.

If we allow, arbitrarily, an interval 0.5 million years for the stratigraphic interval between the base Zanclian and the first evolutionary appearance of a supplementary aperture in Sphaeroidinella, then the Miocene-Pliocene boundary would lie at about 5.5 million years ago. If we use the average rate of sedimentation of $5.0 \mathrm{~cm} / 1000$ years which was calculated for the Pliocene at Site 3 , the Miocene-Pliocene boundary would lie at approximately 463 meters (1519 feet). If we use an average of the rate for the Pliocene $(5.0 \mathrm{~cm} / 1000$ years $)$ and the late Miocene $(3.8 \mathrm{~cm} / 1000$ years), the same boundary would lie at about 455 meters (1493 feet). On the other hand, it has been suggested above that the average rate of sedimentation may have been lower (i.e., similar to that in the late Miocene) in the early part of the Pliocene than in the middle to late part of the Pliocene. In this case, the Miocene-Pliocene boundary might also be expected to lie near 455 meters (1493 feet). Thus, the interval of 455 to 463 meters (1493 to 1519 feet) would appear to limit, within the accuracy of methods available, the interval within which the Miocene-Pliocene boundary may be expected to lie.

For the purposes of this report, the Miocene-Pliocene boundary, estimated to be about 5.5 million years old, is interpreted as lying somewhere between 455 meters and 463 meters (1493 feet and 1519 feet). See Figures 3 - 5.

The time interval during which the lignitic silts and clays of the late Miocene at Site 3 were deposited is not represented by sediments at Site 3 . However, recovery was made of a sample from atop the Challenger Knoll (2) which has been dated as slightly older than the oldest level at Site 3. The oldest level at Site 3 has been estimated to be about 10 million years old; that at Site 2 is estimated at about 12 million years. Between Core 4 at Site 2 at about 100 meters (328 feet) and the top of the cap rock of the dome, at about 136 meters (446 feet), there are 36 meters (118 feet) of sediments. It will be recalled that Core 4 (at about 100 meters (328 feet) has been estimated to be about 3.5 million years old, and that, an average rate of sedimentation of 2.6 $\mathrm{cm} / 1000$ years was estimated for the late Pliocene. If this rate is used in extrapolating downwards, and if a date of 12 million years ago is accepted for the nannoflora horizon, and if we use the level at 136 meters (446 feet) at the top of the dome as being approximately equivalent to that from which the nannoflora was recovered, we obtain the following figures:

$$
\begin{gathered}
100 \mathrm{~m}+(8.5 \mathrm{~m} . \mathrm{y} . \times 26 \mathrm{~m} / \mathrm{m} . \mathrm{y} .) \\
=100 \mathrm{~m}+(221 \mathrm{~m})=321 \mathrm{~m} .
\end{gathered}
$$

A level approximately 12 million years old at Site 2 would be expected to lie at about 321 meters (1053 feet). It occurs at 136 meters (446 feet), or only 36 meters (118 feet) below a level at 3.5 million years ago. Thus, about 185 meters (607 feet) of sediment have been removed by upward movement and compaction of the Challenger Knoll. Had the sedimentary rate dropped by about a half (to $1.3 \mathrm{~cm} / 1000$ years), the 12 million years level would be expected to lie at about 
211 meters ( 692 feet). The total removal of sedimentary section in this case would be about 75 meters ( 247 feet). Evidence from Site 3 suggests that the average rate of sedimentation was about 25 per cent lower in the late Pliocene than in the early Pliocene. If a similar reduction is applied to the average rate of sedimentation at Site 2, the removal of sedimentary section above the Challenger Knoll would have been about 125 meters (410 feet). The significant fact here is that applying the technique of estimated average rate of sedimentation to this site allows an estimate of the amount of sedimentary section which has been removed (extent of the unconformity) during the upward development of the Challenger Knoll.

\section{The Bermuda Rise Sites (6 - 7)}

\section{Paleontology}

Sites 6 and 7 were drilled on the lower, southeastern flank of the Bermuda Rise. Unfossiliferous "red clays" were cored in the upper part of the holes at both sites (Cores 6-1 and 6A-1 at Site 6, and Core 1 at Site 7). In Section 1 and a part of Section 2 in Core 1, at Site 7, coccolith-foraminiferal lutite was found with planktonic foraminifera suggesting a basal Pleistocene age. In view of the depth of water at this site which is 5185 meters $(17,000$ feet), and the fact that this was a surface core, this lutite is probably turbidite-derived.

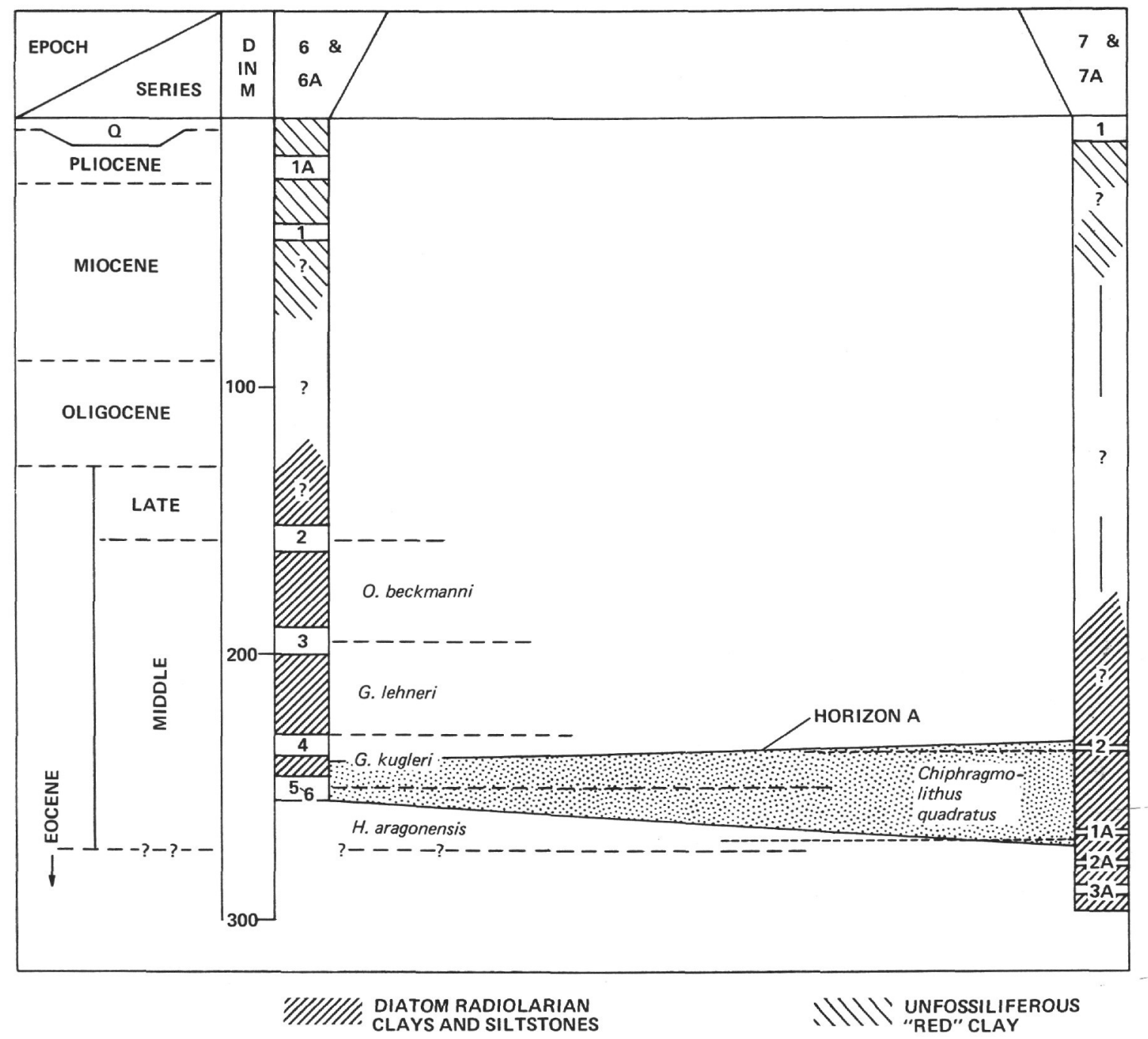

Figure 6. Biostratigraphic Correlation: Bermuda Rise. 
Core 2 at Site 6 is a greenish-buff clay with diatoms and radiolarians which has been tentatively dated by Bukry (see report, this section) as middle to late Eocene in age. Core 3 at Site 6 is a diatom-coccolith mud of Middle Eocene age and has been assigned to the Globorotalia lehneri-Orbulinoides beckmanni zones. Cores 4 through 6 occur within a diatom-radiolarian turbidite sequence in which dark green diatom-radiolarian clays alternate with olive and pale green silts and sands containing transported planktonic and benthonic foraminifera, sponge spicules, terrigenous quartz grains, glauconite, radiolarians, diatoms and nannofossils. Reworking is present in these cores, but appears to be essentially penecontemporaneous as far as the planktonic foraminifera are concerned. No Paleocene or Cretaceous planktonic foraminifera were observed in Cores 4 through 6. A Campanian-Maestrichtian assemblage was found in Core 3, Section 4, however.
Typical Miadle Eocene planktonic foraminiferal forms are found in Cores 4 through 6: Acarinina, Truncorotaloides, Globorotalia and Globigerapsis (Cores 4 and 5). Core 4 is placed within the upper part of the $G$. kugleri Zone; Core 5 within the lower part of the kugleri Zone; and Core 6 within the upper part of the Hantkenina aragonensis Zone.

At Site 7, Core 2 was taken to verify stratigraphic position relative to Site 6 .

No planktonic foraminifera were observed in samples from cores taken at Site 7. On the basis of nannofossils, however (see Bukry and Bramlette, this section), determination of the stratigraphic level of Cores 2 and 7A-1 has been possible and correlation with Site 6 achieved, (see Figure 6). Of particular significance here is the fact that the seismic reflector, tentatively labeled Layer

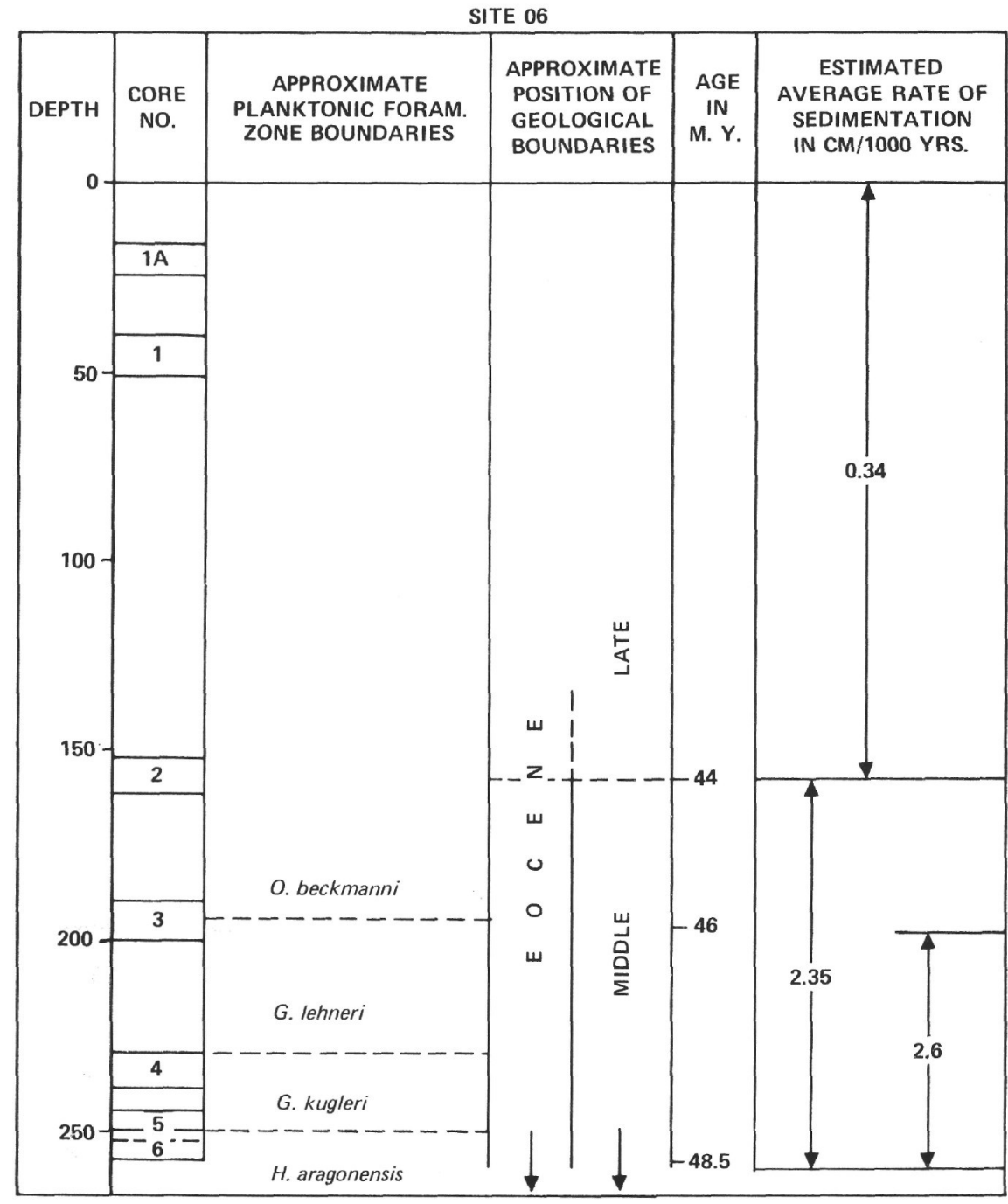

Figure 7. Estimated average rates of sedimentation (cm/1000 yrs) at Site 6 (see discussion in text). 
A in Figure 6 (for a possible alternative explanation, see discussion by Ewing, Worzel \& Burk in Chapter 26, this volume) has been identified as a diatom-radiolarian turbidite sequence of lower Middle Eocene age (Hantkenina aragonensis-Globigerapsis kugleri zones):

\section{Estimated Rates of Sedimentation}

As was the case at Sites 2 and 3 in the Gulf of Mexico, the basic assumption made here is that sedimentation at Site 6 and 7 on the Bermuda Rise has been essentially continuous. The rates estimated here should be considered as approximate and as average rates of sedimentation. The writer believes, nevertheless, that they do reflect qualitatively, at least, real changes which have occurred in the processes of sedimentation at these sites during the Cenozoic. In the following discussion, reference is made to Figure 7.

At Site 6, Core 2 has been approximately dated as Middle to late Eocene. In placing this core approximately at the Middle-late Eocene boundary, an age of 44 million years ago has been assigned to this level. Extrapolating upwards, an average rate of sedimentation of $34 \mathrm{~cm} / 1000$ years is obtained, which is compatable with other estimates on rates of sedimentation of deepsea red-clays. Within the interval encompassed by Cores 1 and 2, the sediments have changed from the red-clays (above) to the green diatom-radiolarian clays (below)

Core 6 at Site 6 is placed in the upper part of the Hantkenina aragonensis Zone. The base of this zone corresponds to the early-Middle Eocene boundary and is dated at about 49 million years. A date of $c a$. 48.5 million years is arbitrarily chosen for the level of Core 6 which is within this zone. In this manner, an average rate of sedimentation of $2.35 \mathrm{~cm} / 1000$ years is obtained for the Middle Eocene diatom-radiolarian clays and turbidite silts at Site 6. In assigning a date of $c a .46$ million years ago to Core 3 at 200 meters' (656 feet), an average rate of sedimentation of $2.6 \mathrm{~cm} / 1000$ years is obtained for the lower half of this sequence. This does not appear unreasonable in view of the fact that the diatom-radiolarian turbidites are primarily developed in the lower part of this sequence at Site 6. On the basis of extrapolation downwards, the early-Middle Eocene boundary at Site 6 is projected to occur at a depth of $c a .270$ meters ( 886 feet).

Cores 7A-2 and 7A-3 were taken in soft clays below the relatively hard diatom-radiolarian turbidite sequence but were, unfortunately, unfossiliferous.

\section{References}

Blow, W. H., (in press, 1969). Late Middle EoceneRecent planktonic foraminiferal biostratigraphy. Proc. First Planktonic Conference., Geneva, (Switzerland) 1967.
Hays, J. H., Saito, T., Opdyke, N. D. \& Burkle, L. H., (in press, 1969). Pleistocene sediments of the equatorial Pacific-their paleomagnetic, biostratigraphic and climatic record. Bull. Geol. Soc. Am.

\section{MESOZOIC PLANKTONIC FORAMINIFERA AND RADIOLARIA}

\author{
E. A. Pessagno, Jr. \\ S. W. Center for Advanced Studies, \\ Dallas, Texas
}

\section{General}

Mesozoic planktonic foraminifera and Radiolaria were encountered primarily in the Bahama area near San Salvador (Holes 4, 4A, 5 and 5A). Hence, the biostratigraphic synthesis to follow is largely one dealing with the Bahama sites.

Planktonic foraminifera in the Bahama cores occurred sporadically in strata ranging in age from early Maestrich tian to Albian. At most horizons, planktonic foraminifera were either absent or sparse. Samples rich in planktonic foraminifera occurred only in Cores 1 and 2 from Hole 4A. Planktonic foraminifera were invariably associated with turbidites. Intervals between turbidite layers were generally barren of foraminifera, but usually contained common Radiolaria and abundant coccoliths.

It is believed that sedimentation during Cenozoic and Mesozoic times in the Bahama area (Sites 4 and 5) took place at about 5180 meters $(17,000$ feet $)$-essentially the depth of the present sea floor. Furthermore, it is likely that deposition occurred for the most part below the depth of compensation of the calcite comprising planktonic foraminiferal tests. Hence, foraminiferal tests were dissolved before they had a chance to be incorporated in the sediments. A few planktonic foraminifera were preserved in turbidites although they are frequently masked by shallow water molluscan fragments (e.g., rudistid fragments), bryozoan fragments, benthonic foraminifera, and so forth. Assumedly, in such cases, deposition and subsequent burial were rapid enough to prevent their solution. Oddly enough, the nannofossils, which likewise consist of calcite, were preserved in great abundance in Mesozoic sediments at Sites 4 and 5. It is likely, however, that the coccoliths may have been protected from solution by organic protective jackets.

The Cretaceous planktonic foraminiferal assemblage appears to be Tethyan in aspect. For example, in the latest Campanian to earliest Maestrichtian assemblage present in Core 1, Hole 4A (Samples 3 through 5), Planoglobulina multicamerata de Klasz (see Plate 10C) is profusely abundant. Investigations that the writer (Pessagno 1967, 1968) undertook on the Tethys faunas of Mexico and Puerto Rico indicate that $P$. multicamerata 
is abundant in strata ranging in age from late Campanian ( $G$. elevata Subzone) to early Maestrichtian (R. subcircumnodifer Subzone). However, in the southern portion of the Boreal faunal province in Texas and southwestern Arkansas, this species is rare in strata of this age. The presence of a penecontemporaneously reworked larger foraminiferal assemblage containing Vaughanina cubensis minor Seiglie and Ayala-Castanres, Sulcoperculina globosa de Cizancourt, Conorbitoides cristalensis Bronnimann, and Orbitoides sp. cf. O. tissoti Schlumberger likewise tends to confirm the Tethyan aspect of the foraminiferal assemblage (See report from K. N. Sachs, Chapter 18).

A number of planktonic species which are represented abundantly in shore-based sections are absent in the rich late Campanian to early Maestrichtian samples of Core 1 (Hole 4A), the early Cenomanian samples of Core 2 (Hole 4A) and Core 3 (Hole 4), and the late Albian sample of Core 3 (Hole 4). For example, in the late Campanian and early Maestrichtian samples, only four species of Heterohelicids are present: Pseudoguembelina costulata (Cushman), Pseudotextularia elegans (Rzehak), Planoglobulina multicamerata (de Klasz), and Heterohelix punctulatus (Cushman) as opposed to eight or more species elsewhere at the same horizon in the Tethys faunal province (e.g., Puerto Rico). Similarly, in the late Albian and early Cenomanian faunal elements such as Hedbergella washitensis (Carsey), Heterohelix moremani (Cushman), and Guembelitria harrisi Tappan which are usually abundant or at least common at the same horizons elsewhere in the Tethys faunal province are absent. The reasons for the negative aspect of the planktonic foraminiferal assemblage are not immediately apparent. The absence of a number of species of Heterohelicids may perhaps be a reflection of more open sea conditions. It is conceivable that the Heterohelicidae are both more diversified and abundant in a neritopelagic environment than they are in a bathypelagic or abyssopelagic environment.

Radiolaria were common to abundant in strata of early Santonian-late Turonian to late Jurasic (Tithonian) age in the Blake-Bahama Basin area. However, since Mesozoic Radiolaria are still poorly studied, they could not be utilized, in most instances, to their full biostratigraphic potential. Indeed, the majority of the species encountered in early Cretaceous and late Jurassic strata appear to be new and yet undescribed. Studies (Pessagno, in progress) on the Upper Cretaceous Radiolaria of the California Coast Ranges indicate that Radiolaria can be used to establish detailed systems of zonation. In that a great amount of faunal change in the Bahama radiolarian assemblage occurred between late Jurassic and Albian times, it is likely that Radiolaria can be utilized to develop a detailed system of zonation for strata of this age. A few specimens of early Cretaceous and late Jurassic Radiolaria are figured herein (Plates 4 through 8 ).
It is hoped that these illustrations may prove useful in future phases of the Deep Sea Drilling Project.

Radiolaria occurred in both turbidites (e.g., Sample 6, Hole 4, Core 2) and normal abyssal oceanic pelagic sediments (e.g., Sample 10, Hole 5A, Core 7). The richest radiolarian samples were recovered from pelagites at Hole 5A in Core 3 (Sample 6) and in Core 7 (Sample 10) which were Albian and late Jurassic to Tithonian, respectively. Radiolaria in the Bahama cores were either calcified, pyritized, or still silicified. Most calcified specimens were too poorly preserved for the purpose of identification. However, most of the silicified material and some of the pyritized material was well preserved.

No Radiolaria were encountered at Leg 1 sites in strata younger than Middle Eocene. Recent Radiolaria are apparently rare in bottom sediments at middle latitudes in the Atlantic although they are common in plankton tows. An explanation for this anomalous situation is still forthcoming.

\section{Correlation of Mesozoic Strata in the Blake-Bahama Basin Area}

Correlation of strata in the Bahama area is indicated in Figure 8. This correlation chart was compiled from biostratigraphic data resulting from the study of the planktonic foraminifera, nannofossils, and the Radiolaria.

The late Jurassic (Tithonian) dating of Core 7 (Hole 5A) supplied by the nannofossils is also supported by radiolarian data. Spongosaturnalisdicranocanthos (Squinabol) has been figured by Squinabol (1914, pp. 289-291) from the Jurassic of Italy. The Jurassic radiolarian assemblage present in Core 7 contains many forms that are analogous or identical to those figured by Rust $(1885,1898)$, Parona (1890), and others (see Plate 4, A-P).

The Albian and Cenomanian boundary probably occurs between Sample 10 (Hole 4, Core 3, Section 1: 55 to 57 $\mathrm{cm}$ ) and Sample 11 (Hole 4D, Core 3, Section 1: 100 to $102 \mathrm{~cm}$ ) at Site 4 . The fauna at the 55 to 57 centimeter interval is definitely early Cenomanian (Rotalipora evoluta Subzone), whereas that at the 100 to 102 centimeter level is probably late Albian. The probable late Albian age of Sample $11(100$ to $102 \mathrm{~cm})$ is based on negative evidence, i.e., the lack of Rotalipora evoluta Sigal.

It would appear that almost all of the Rotalipora evoluta Subzone of Pessagno $(1967,1968)$ is represented between Hole 4, Core 3, Section 1: 55 to 57 centimeters and Hole 4A, Core 2, Section 1: 109 to 111 centimeters (cf. Samples 8 through 10). Sample 8 contains abundant Rotalipora appenninica s.s. (O. Renz), and a single specimen of $R$. greenhornensis (Morrow). Neither of these species are present in Samples 9 and 10. In that 


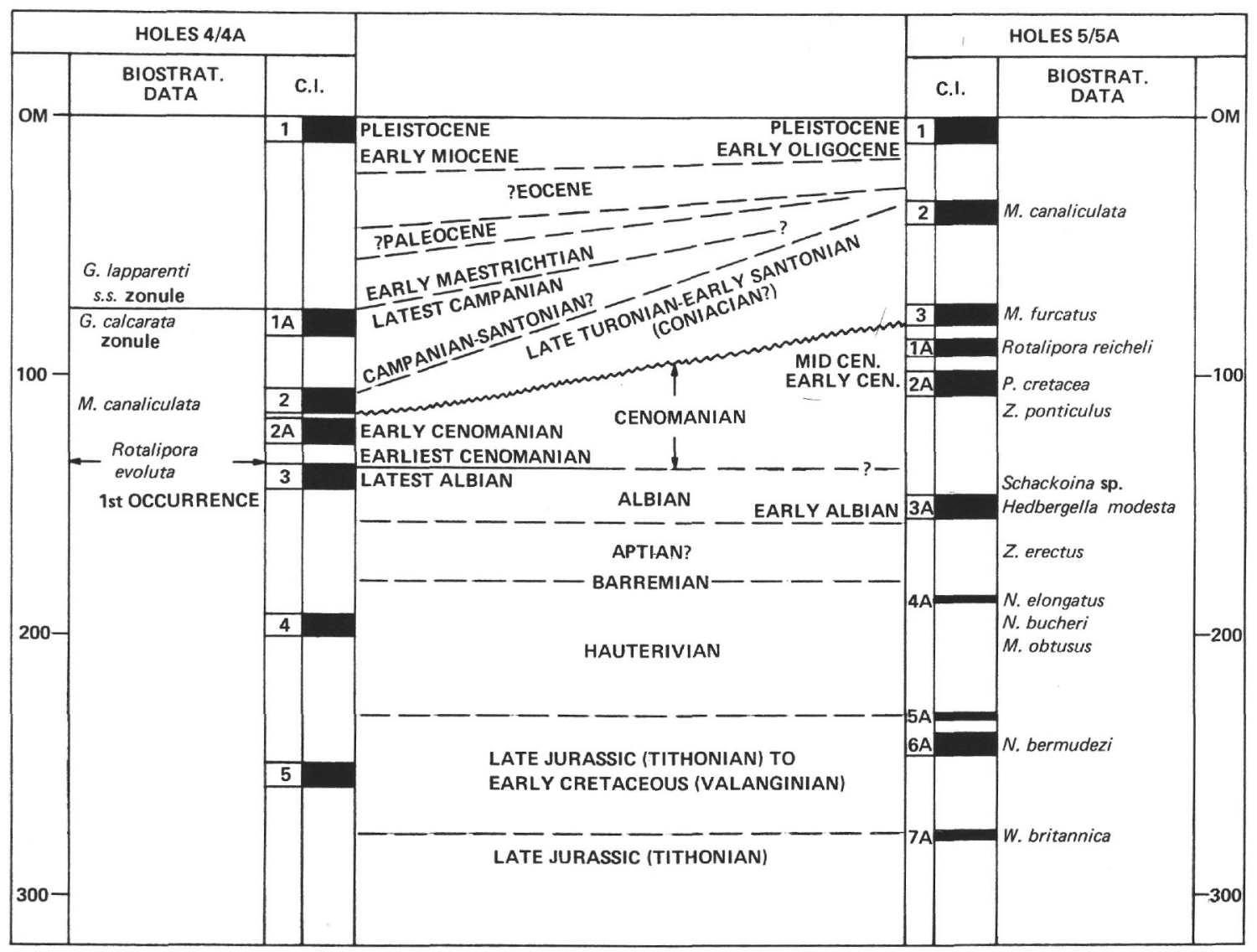

Figure 8. Correlation chart for Bahama Basin (Sites 4 and 5).

$R$. appenninica and $R$. greenhornensis are both abundant in the $R$. cushmani-greenhornensis Subzone of Pessagno $(1967,1968)$, it is likely that Sample 8 is representative of the upper part of the R. evoluta Subzone.

Sample 10 contains Rotalipora montsalvensis Mornod and Rotalipora balernaensis Gandolfi in association with Rotalipora evoluta Sigal. Although both of these species are well known from the early Cenomanian of Europe, this is the first instance in which they have been recorded from the early Cenomanian of the Western Hemisphere.

At both Sites 4 and 5 a pronounced disconformity separates strata of early Cenomanian age from strata of early Santonian and late Turonian (Coniacian?) age. Strata of early Turonian, late Cenomanian, and late early Cenomanian (lower part of $R$. cushmani-greenhornensis Subzone) are absent. Some Cenomanian elements seem to have been reworked into strata of early Santonian to late Turonian age at Site 4 (see faunal list for Sample 6, in Chapter 4).

The early Santonian to late Turonian age of Sample 6 (Hole 4) is based on: (a) the range zone and occurrence of Marginotruncana canaliculata (Reuss) (see neotype erected for $M$. canaliculata (Reuss) by Pessagno 1967), and (b) the range zones and occurrence of Pseudoaulophacus gallowayi White, P. lenticulatus White, P. pargueraensis Pessagno, and Dictyomitra multicostata s.l. Zittel. The early Santonian to late Turonian age of Sample 3 (Hole 5) is based primarily on the range zone and occurrence of M. canaliculata (Reuss).

The Maestrichtian-Campanian boundary may occur within the top eight centimeters of Core 1, Hole 4A. The lack of the Campanian indices Globotruncana ventricosa, White and Globotruncana calcarata Cushman at the top of Core 1 (Sample 3) and their presence in a sample (Sample 4) collected 9 to 10 centimeters from the top of Core 1 tends to substantiate this conclusion.

\section{REFERENCES}

Aliev, Kh. Sh., 1961. New Radiolarian Species of the Lower Cretaceous deposits of North Eastern Azerbaidzhan. Bull. Acad. Sciences Azerbaidzhan SSR, Series of the geological-geographical sciences and oil, 1961. (1), 51-63.

Parona, C. F., 1890. Radiolarie nei noduli selciosi del calcare giurese di Cittiglio presso Laveno. Boll. Soc. Geol. Ital. 9, 1. 


\section{PLATES 4 THROUGH 12}

\section{PLATE 4}

Late Jurassic (Tithonian) Radiolaria from Hole $5 A$, Core 7, Section 1: Top. All specimens somewhat recrystallized but still siliceous.

A-B Spongosaturanalis dicranocanthos (Squinabol). Lower portion of ring structure broken on both specimens. $S$. dicranocanthos is one of the more abundant elements in the faunal assemblage. Markers on both specimens equal 150 microns.

C "Theosyringium amaliae" Parona? This form is quite abundant as well as distinctive. Marker equals 250 microns.

D Undescribed Spumellariinid. Marker equals 75 microns.

E Undescribed Nassellariinid. Marker equals 250 microns.

F Undescribed Nassellariinid. This form is analogous to forms figured from the Jurassic. Marker equals 150 microns.

G-H "Lithocampe" mediodilatata Rust? Numerous forms similar to but not identical to the figured specimen have been illustrated from the Jurassic. $\mathrm{G}$ marker equals 250 microns. $\mathrm{H}$ marker equals 75 microns.

I “Amphibrachium”n. sp. Quite abundant in faunal assemblage. Marker equals 250 microns.

J Triactinosphaera n. sp. Abundant in faunal assemblage. Marker equals 250 microns.

K Triactinosphaera? n. sp. Abundant in faunal assemblage. Marker equals 250 microns.

L "Rhopalastrum(?)" spinosum Parona. Marker equals 100 microns.

M Triactinosphaera n.sp. Marker equals 150 microns.

N Spumellariinid. Marker equals 150 microns.

O Triactinosphaera(?) n. sp.

P Triactinosphaera(?) n. sp. Marker equals 100 microns.

\section{PLATE 5}

Scanning electron micrographs of Albian Nassellariina from Hole 5A, Core 3, Section 1: Core Catcher.

A, B Markers equal 50 microns. Figure A is Dictyo-

\& D mitza malleola Aliev (1961, p. 62, pl. 2, figs. 5-7), previously recorded from Albian-Cenomanian of the USSR.

C Marker equals 75 microns.
PLATE 6

Scanning electron micrographs of Albian Radiolaria from Hole 5A, Core 3, Section 1: Core Catcher.

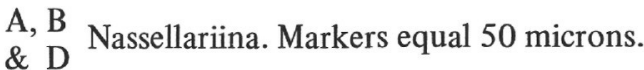

C Spongosaturnalis sp.

PLATE 7

Scanning electron micrographs of Albian Spumellariina from Hole 5A, Core 3, Section 1: Core Catcher.

A Spongodiscacea of this sort likewise appear in the Upper Cretaceous strata of the California Coast Ranges. In transmitted light they display a concentric arrangement of pore frames. Marker equals 150 microns.

B, C
\& D Spongodiscacea. Markers equal 75 microns.

\section{PLATE 8}

Scanning electron micrographs of Early Cretaceous Radiolaria.

A Pseudoaulophacus n. sp. from Hole 5A, Core 3, Section 1: Core Catcher. This form superficially resembles $P$. gallowayi White. Albian. Marker equals 50 microns.

B-C External and internal view of spaeroid Spumellariinid from Albian: Hole 5A, Core 3, Section 1: Core Catcher. Marker equals 50 microns.

D “Melitosphaera" sp. aff. "M." sphaeroconus Rust. Pyritized specimen from Neocomian(Hauterivian). Hole 4, Core 4, Section 1: 5 through 8 centimeters. Marker equals 50 microns.

\section{PLATE 9}

All figures are scanning electron micrographs of planktonic foraminifera from Hole 4A, Core 1, Section 1: 9 to 10 centimeters.

A Globotruncana stuartiformis Dalbiez. Peripheral view. Marker equals 150 microns.

B Globotruncana calcarata Cushman. Spiral view. Marker equals 150 microns.

C Globotruncana linneiana (d'Orbigny). Spiral view. Marker equals 150 microns.

D Globotruncana ventricosa White. Peripheral view. Marker equals 150 microns.

PLATE 10

All figures are scanning electron micrographs.

A Globotruncana fornicata Plummer. Hole 4A, Core 1, Section 1: 9 to 10 centimeters. Spiral view. Marker equals 150 microns. 
B Globotruncana nothi (Bronnimann and Brown). Spiral view. Hole 4A, Core 1, Section 1: Top. Marker equals 75 microns.

C Planoglobulina multicamerata de Klasz. Hole 4A, Core 1, Section 1: Top. Marker equals 150 microns.

D "Heterohelix" punctulatus (Cushman). Hole 4A, Core 1, Section 1: Top.

PLATE 11

All illustrations are scanning electron micrographs of specimens from Hole 4, Core 3, Section 1: 55 through 57 centimeters.

A Rotalipora evoluta Sigal. Spiral view. Marker equals 50 microns.

B Rotalipora evoluta Sigal. Umbilical view. Marker equals 75 microns.

C Rotalipora montsalvensis Mornod. Anti-apertural peripheral view. Marker equals 75 microns.
D Globigerinelloides caseyi Bolli, Loeblich, and Tappan. Side view. Marker equals 50 microns.

\section{PLATE 12}

All illustrations are scanning electron micrographs of specimens from Hole 4, Core 3, Section 1: 55 through 57 centimeters.

A Praeglobotruncana delrioensis (Plummer). Peripheral view. Note imperforate peripheral band (keel?). Only about 1 out of 10 individuals display imperforate peripheral bands. Marker equals 50 microns.

B Praeglobotruncana delrioensis (Plummer). Spiral view. Marker equals 50 microns.

C Praeglobotruncana delrioensis (Plummer). Umbilical view. Marker equals 75 microns.

D Hedbergella planispira Tappan. Spiral view. Marker equals 50 microns. 
PLATE 4.
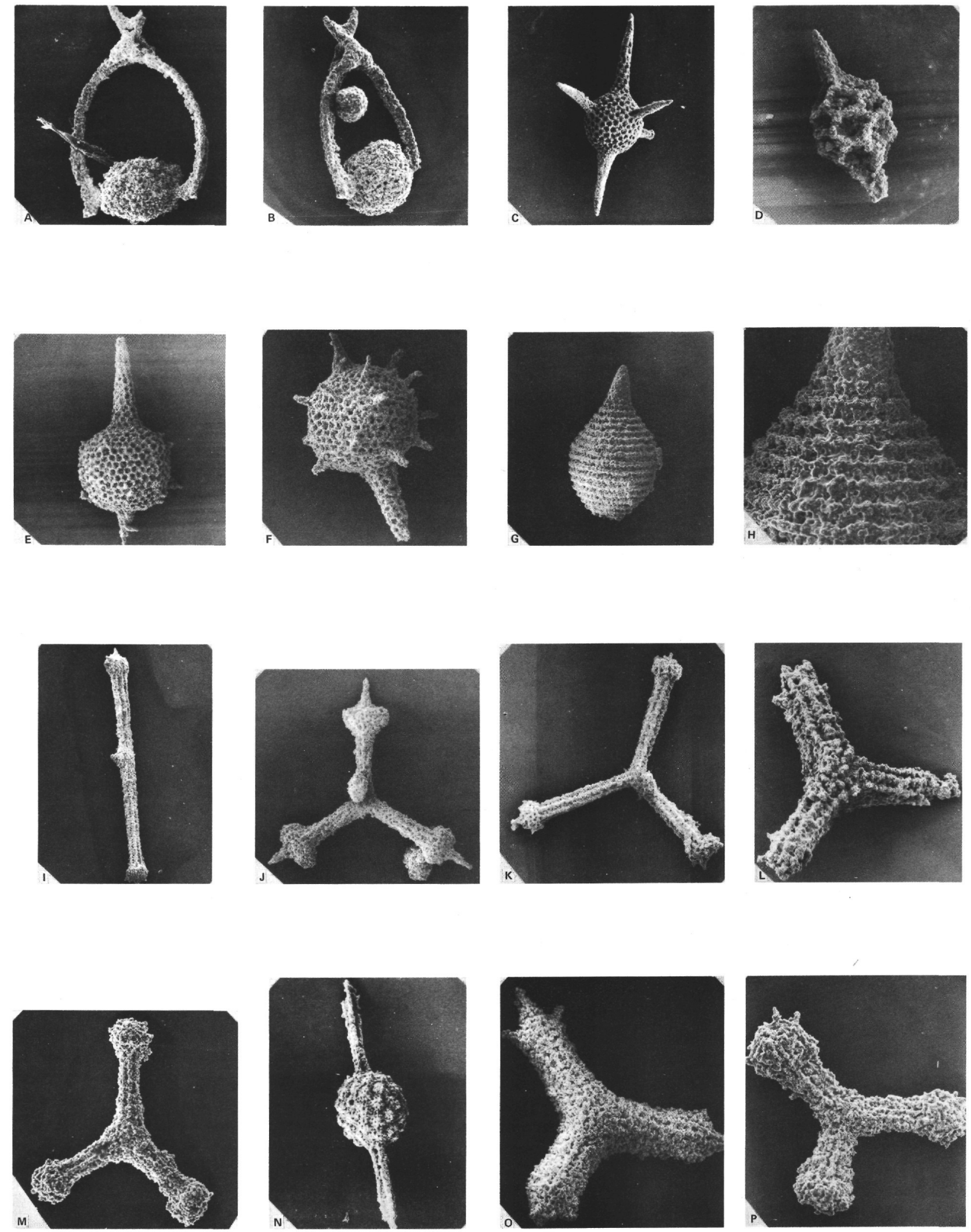
PLATE 5.
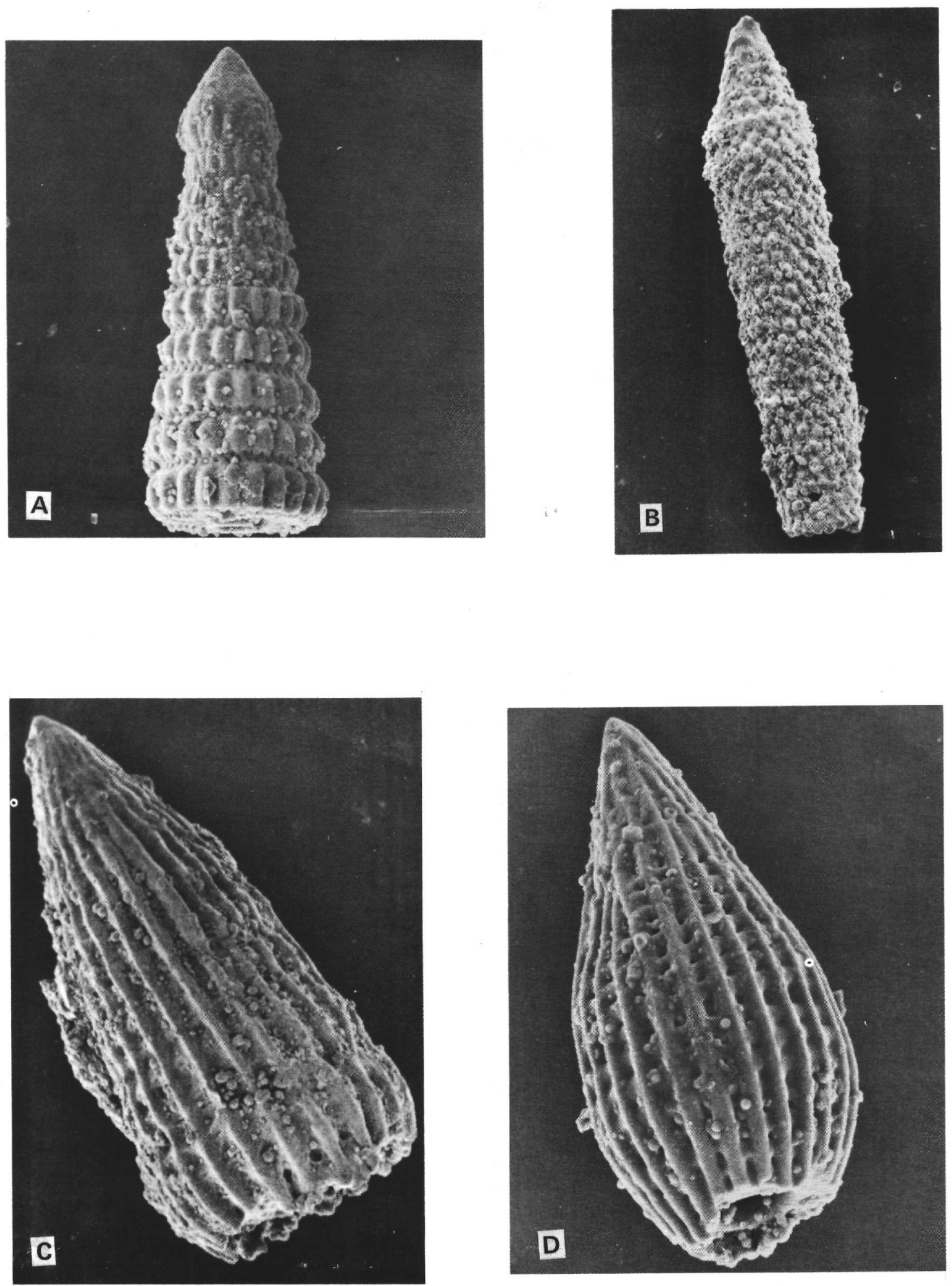
PLATE 6.
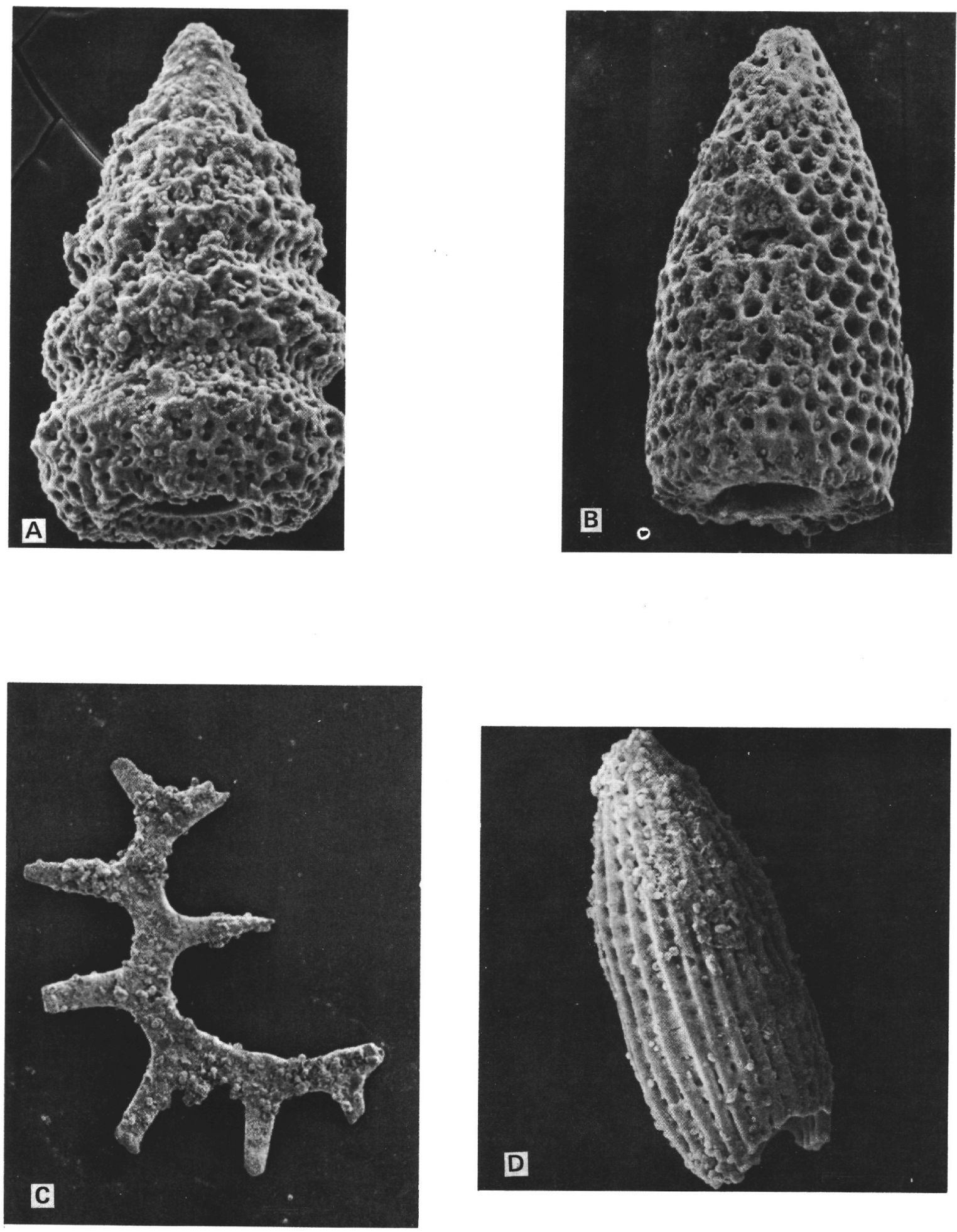
PLATE 7.
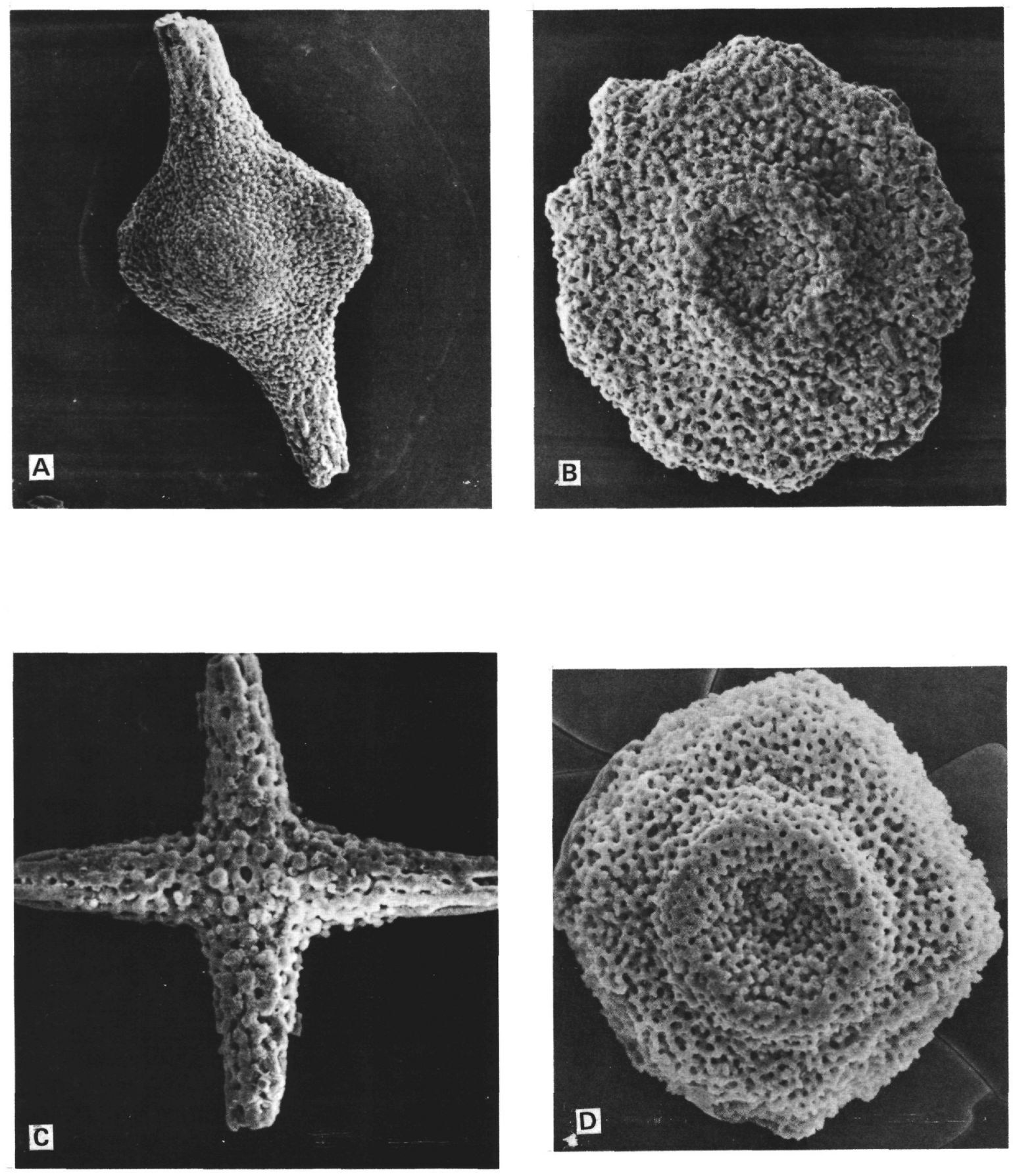
PLATE 8.
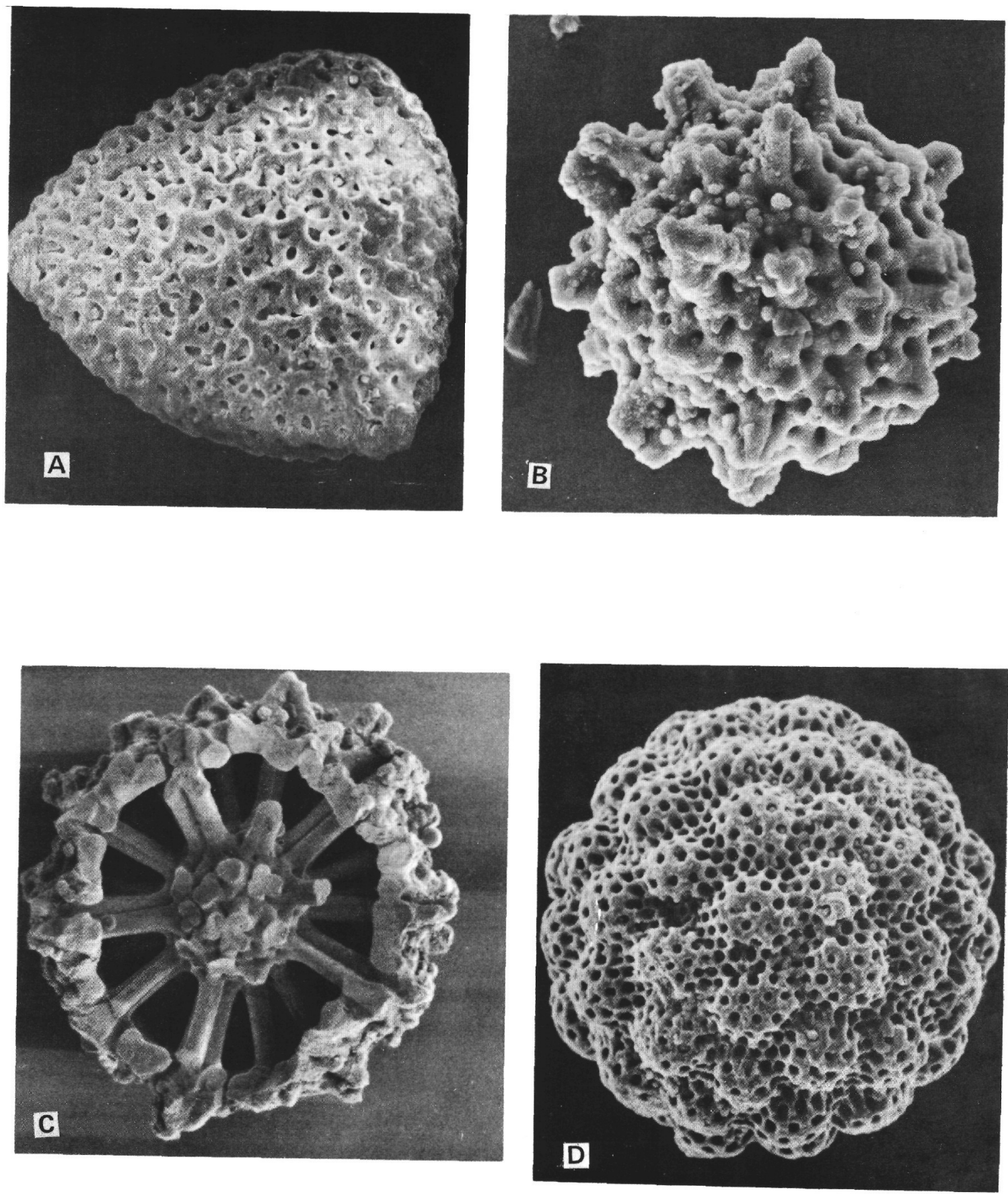
PLATE 9.
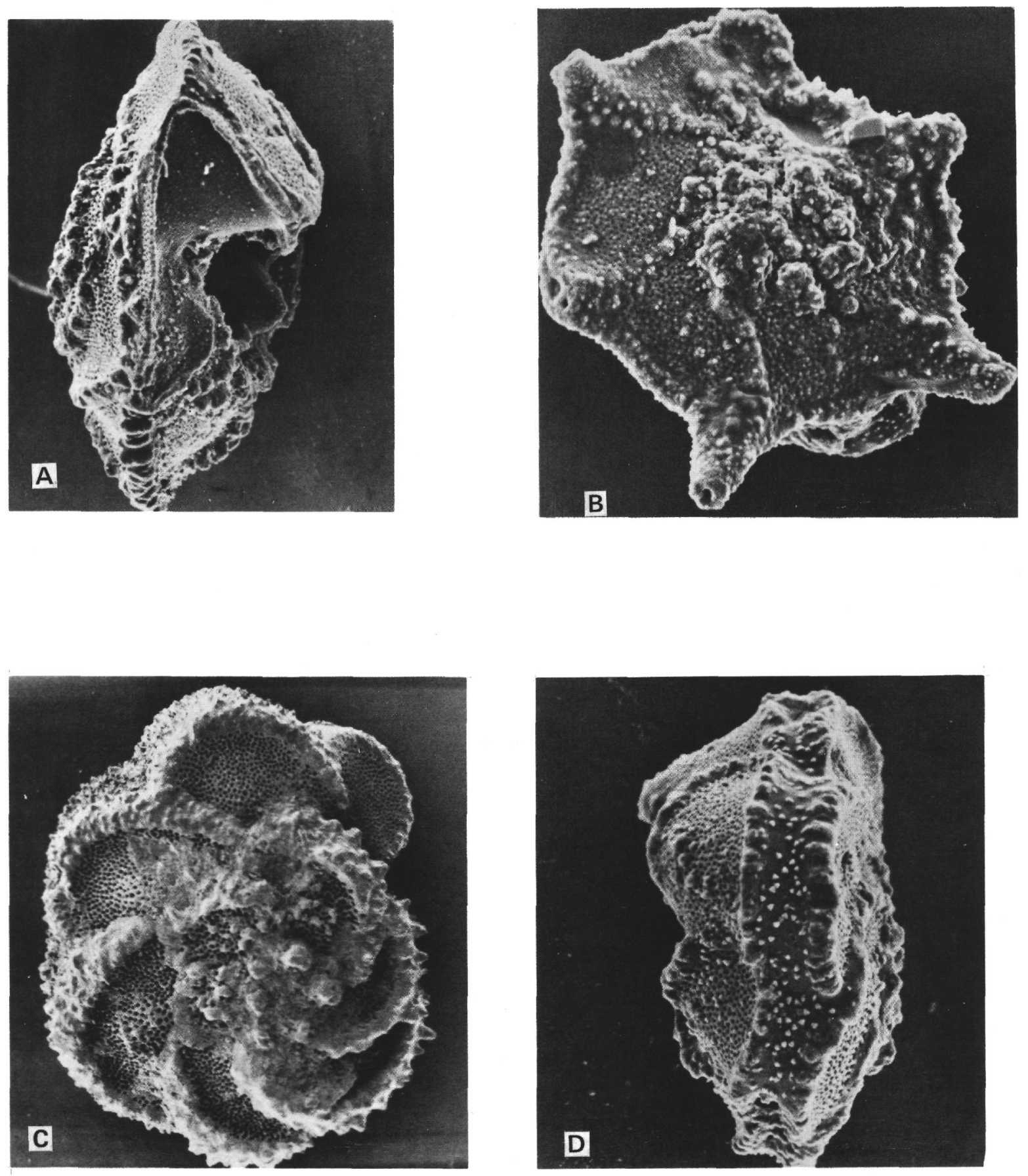
PLATE 10.
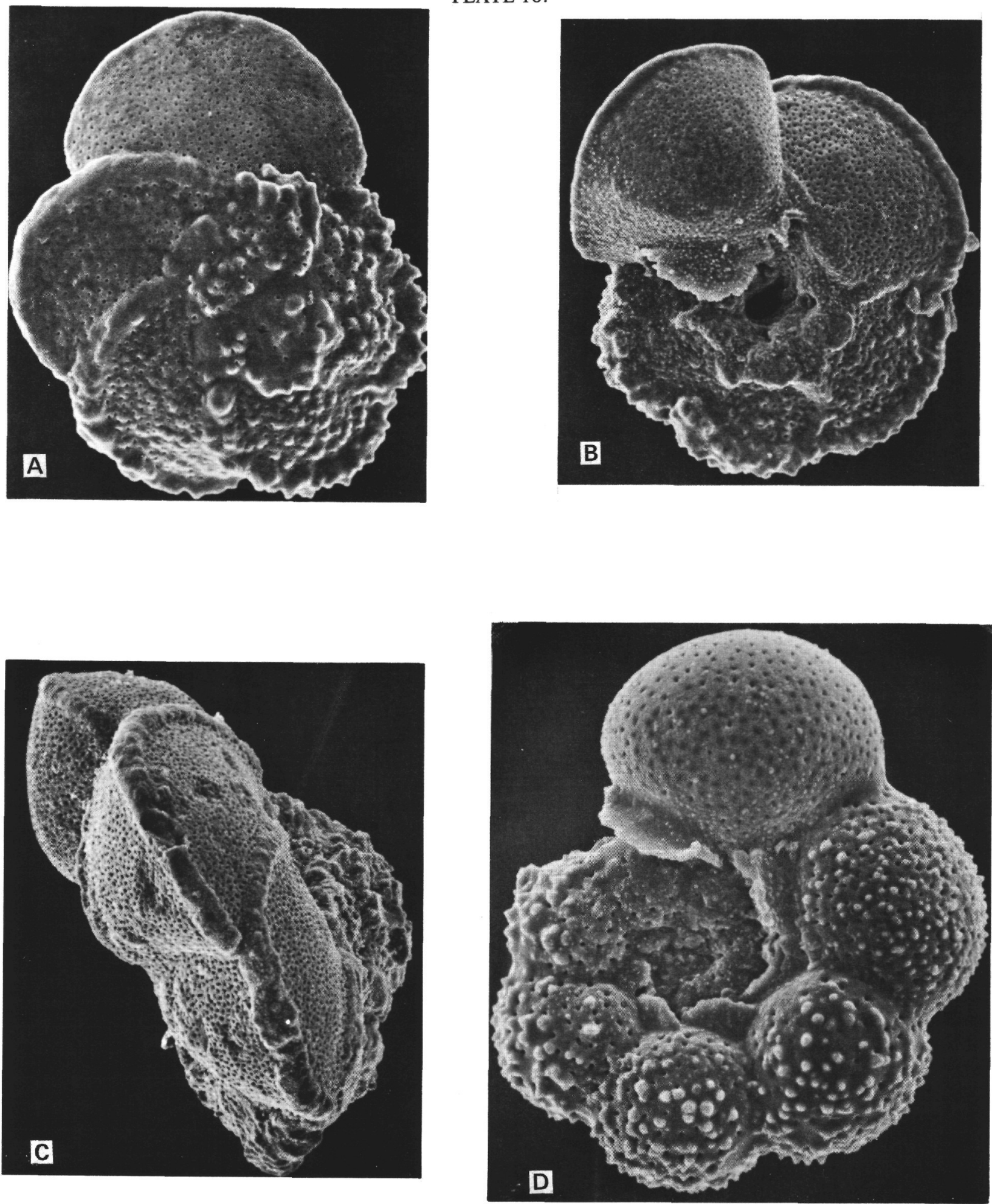
PLATE 11.
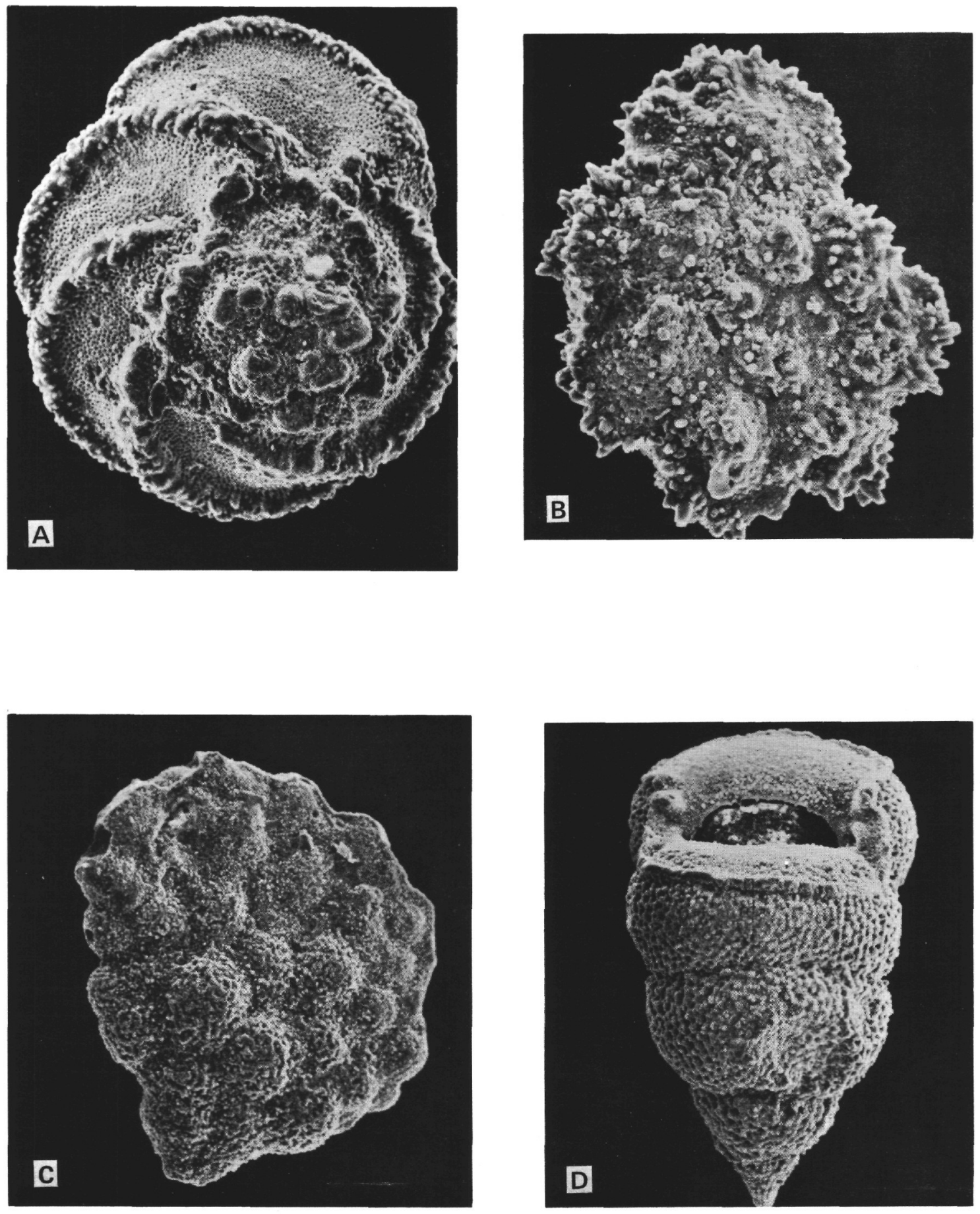
PLATE 12.
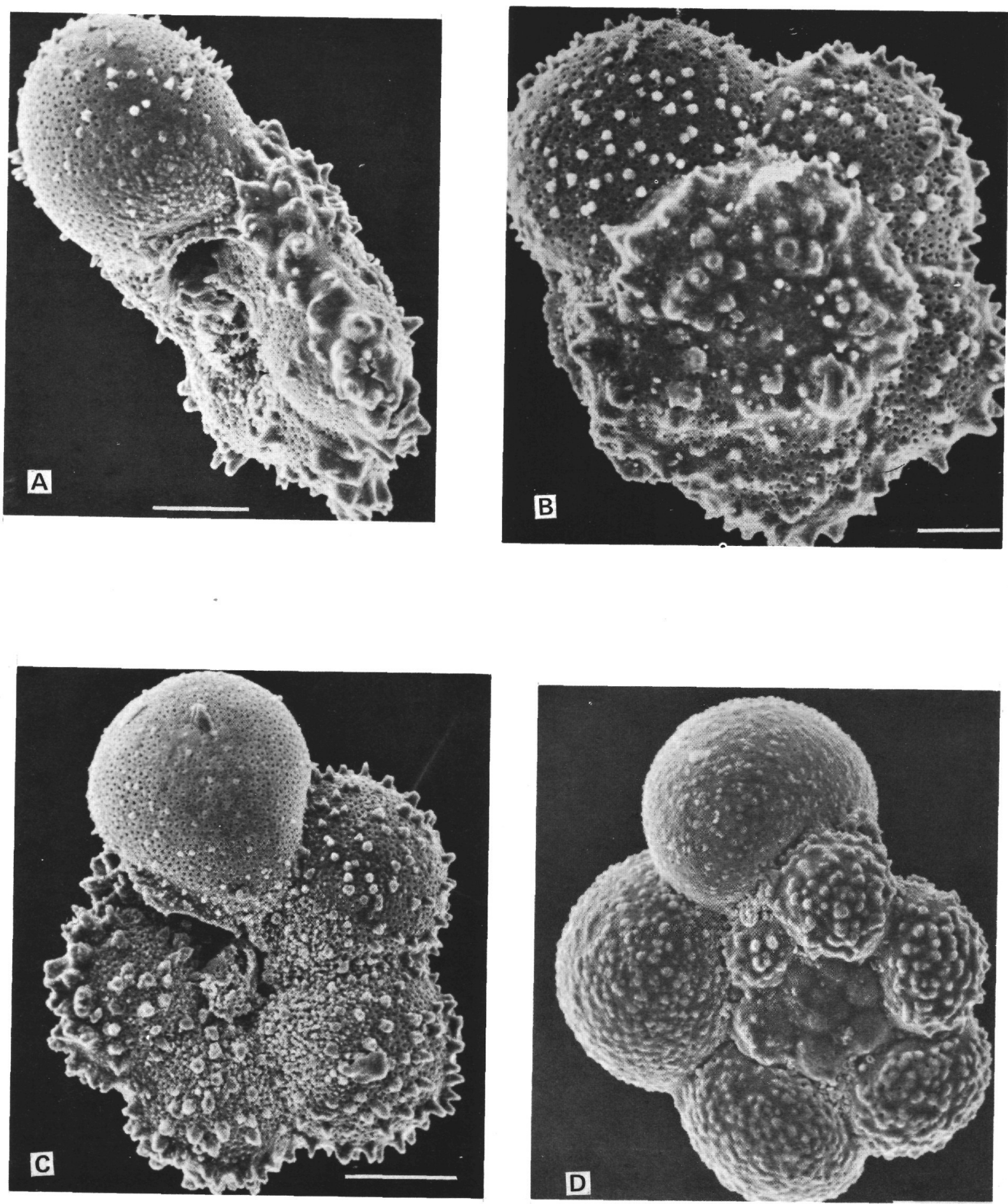
Pessagno, Emile A., Jr., 1967. Upper Cretaceous planktonic foraminifera from the western Gulf Coastal Plain. Paleontographica Americana. 5 (37), 245.

(in press) 1968. Upper Cretaceous stratigraphy of the western Gulf Coastal Plain area of Mexico, Texas, and Arkansas. Geol. Soc. Amer., Mem., No. 111 .

Rust, David, 1885. Beitrage zur Kenntniss der fossilen Radiolarien aus Gesteinen des Jura. Paleontographica. 31 (ser. 3, Vol. 7), 269.

. 1898. Neue Beitrage zur Kenntniss der fossilen Radiolarien aus Gesteinen des Jura und der Kreide. Palaeontographica. 45, 1 .

Squinabol, Senofonte, 1914. Contributo alla conoscenza dei Radiolarii fossili del Veneto. Appendice-Di un genere di Radiolari caratteristico del Secondario. Mem. 1st Geol. Mineral Univ. Padova. 2, 249.

\section{SUMMARY OF COCCOLITH BIOSTRATIGRAPHY}

\author{
David Bukry ${ }^{1}$ \\ U. S. Geological Survey, La Jolla, California \\ and \\ M. N. Bramlette
}

Scripps Institution of Oceanography, La Jolla, California

The holes drilled during Leg 1 at seven sites investigated the geology of the ocean floor in three major areas: The Gulf of Mexico (Holes 1, 2, and 3), the Blake-Bahama Basin (Holes 4, 4A, 5, and 5A), and the Bermuda Rise (Holes 6, 6A, 7, and 7A). A total of 56 drilled cores and 1 piston core were recovered, and an attempt was made to date 51 of these using fossil coccoliths. Although 7 cores contain only barren deep-sea red clay or chert, the other 44 recoveries contain age-diagnostic coccoliths. In 17 core recoveries, coccoliths are the only microfossils present that can be used for age determination. The success in supplying ages based on coccolith assemblages is largely due to the great abundance and near omnipresence of these microfossils in marine sediment deposited from early Jurassic time (180 million years ago) until the present. This time span takes in the age of all presently dated sediments in the ocean basins.

\section{Gulf of Mexico (Holes 1, 2, and 3)}

Three drilling sites in progressively deeper water were chosen to investigate late Tertiary sedimentation in the Gulf of Mexico. The hole drilled at Site 1, beyond the base of the continental shelf of the Gulf Coast, recovered samples from a thick upper Pleistocene sequence that is distinctive in its abundance of land derived detritus, including numerous reworked Cretaceous coccoliths. In sharp contrast, Hole 2, which was drilled on one of the Sigsbee Knolls 180 meters (590 feet) above the surrounding abyssal plain, penetrated a thinner but presumably complete Pleistocene section of pelagic

\footnotetext{
${ }^{1}$ Publication authorized by the Director, U. S. Geological Survey
}

microfossil ooze with less terrigenous material or reworked coccoliths. For purposes of stratigraphic comparison, Hole 3 , which was drilled nearby on the abyssal plain, contains an upper Pleistocene section that is rich in terrigenous material and reworked Cretaceous coccoliths and a lower Pleistocene section of pelagic sediment and carbonate turbidite beds similar to, but thicker than, the section seen at Hole 2. These occurrences indicate that pelagic sedimentation prevailed in the locally high area of Hole 2 on Challenger Knoll throughout the Pleistocene but that a strong influx of terrigenous material influenced sedimentation at Holes 1 and 3 , at least during the later Pleistocene.

The Pliocene section at Hole 2 is about 50 meters (164 feet) thick, whereas, that at Hole 3 is 250 meters (820 feet) thick, and the Upper Miocene at Hole 3 is also thicker than at Hole 2. This contrast in sediment thickness resulted from thinning over the Challenger Knoll piercement salt dome as turbidite beds made up a greater part of the stratigraphic section on the adjacent abyssal plain at Hole 3 . Hence, while the three individual holes contrast markedly in thickness of units, they are clearly related by their lithologic and paleontologic stratigraphy.

The Pleistocene and Pliocene coccolith assemblages are similar to those previously known from the Gulf of Mexico and elsewhere, but the Miocene assemblages recovered during Leg 1 are quite distinctive for their paucity of oval and circular coccoliths and their predominance of star shaped discoasters. Most Miocene coccolith assemblages contain a majority of the oval and circular coccoliths. Therefore, it seems likely that Miocene turbidity currents winnowed the smaller coccoliths out of the samples recovered. This conclusion is also supported by the fact that especially large discoasters are concentrated in these same samples.

\section{Blake-Bahama Basin (Holes 4, 4A, 5, 5A)}

Surface cores at Sites 4 and 5 indicate that only a thin veneer of Tertiary sedimentary deposits cover this region. Fifteen cores taken from subbottom depths of 31 to 250 meters (102 - 820 feet) contain Cretaceous sediment ranging in age from Valanginian to Maestrichtian, and one core at 274 meters (900 feet) held late Jurassic (Tithonian) sediment. At least local continuity of this marine Mesozoic section is indicated by the nonconflicting superposition of coccolith dated strata between the two doubly drilled Sites 4 and 5, which are 30 kilometers apart. The Cretaceous is here represented by about 220 meters of sediment. Instead of continuous slow pelagic deposition of coccolith ooze during the 70 million years of the Cretaceous at the indicated rate of about 3 millimeters per thousand years, the presence of turbidite layers and the seeming absence of Turonian and Aptian deposits suggest that this section records numerous episodes of submarine erosion. As coccoliths 
are abundant throughout the cores, it is assumed that this area was usually a productive open marine environment, with a bottom depth above that at which calcite undersaturation would cause coccoliths to be dissolved. The Tithonian age of the deepest core in this area is older than any previously known oceanic core, and reflection profiles in the area show acoustically transmissive beds down to at least 670 meters below the bottom. Apparently, more than 400 meters (1312 feet) of even older marine sediment remains to be sampled in this basin.

\section{Bermuda Rise (Holes 6, 6A, 7, and 7A)}

Our previous lack of knowledge of conditions below the ocean floor is well represented in the area of Sites 6 and 7. It was forecast that continuous coring there would provide microfossil-bearing stratigraphic sequences of pelagic calcareous sediment bridging the CretaceousTertiary boundary. The cores revealed a quite different, but nonetheless, intriguing stratigraphy. Deep-sea red clay, generally barren of calcareous microfossils, dominates the near surface sediment. However, Pliocene coccoliths occur in the red clay at 16 meters (52.5 feet) in Hole 6A, and a sequence of coccoliths in red clay bridges the Pliocene-Pleistocene boundary in the top three meters of Hole 7. The next cored interval below the red clay contains a remarkable sequence of green turbidite and chert beds that is rich in calcareous and siliceous skeletal remains of Middle Eocene microorganisms. Drilling was so difficult in the hard chert that not only was any attempt at continuous coring through the Cretaceous and Tertiary dismissed, but paramount interest was focused on the problem simply of penetrating the Middle Eocene rocks. These, although some 80 meters (263 feet) thick, represent only the time span of a single microfossil zone-approximately two million years. Eventually, two cores were recovered from below the chert. The sediment there is again nonfossiliferous clay. Its presence suggests that the ocean floor has been very deep here for at least the past 50

\section{REFERENCES}

Bolli, H. M., 1966. Zonation of Cretaceous to Pliocene marine sediments based on planktonic foraminifera. Bol. Assoc. Venezolana Geologia Mineria y Petroleo. 9 (1), 3.

Bramlette, M. N., and Wilcoxon, J. A., 1967. Middle Tertiary calcareous nannoplankton of the Cipero section, Trinidad, W. I. Tulane Studies Geology. 5,93 .

Bukry, D., 1969. Upper Cretaceous coccoliths from Texas and Europe. Univ. Kansas Publ. State Geol. Surv. Kansas Bull., Protista. art. 2, 79 p.

Bukry, D., and Bramlette, M. N., 1968. Stratigraphic significance of two genera of Tertiary calcareous nannofossils. Tulane Studies Geology. 6, 149. million years. Early in this period, during Middle Eocene time, great quantities of fossiliferous sediment were swept into the area by submarine currents and cemented by silica. Hence, important keys to the history of the ocean floor and to the processes that have shaped it lie in samples such as these recovered from the Bermuda Rise.

\section{Age Determination of Deep-Sea Sediment by Coccoliths}

One great value of coccoliths to deep-sea research is the speed with which they can be used to date a sample. A simple smear slide, containing more than 100,000 coccolith specimens, can be prepared and examined under a microscope within a few minutes. Thus, aboard the ship it was possible to identify diagnostic species and determine the age of a core within five minutes of its recovery.

An additional advantage of coccolith dating is based on their small size (average diameter 7 microns). Even the smallest amount of sediment recovered during coring can be dated to add to the geologic information about a drill site. For instance, at Hole $4 \mathrm{~A}$ which was drilled to recover relatively deep Cretaceous sediment, the first coring was not attempted until after 72 meters (236 feet) of subbottom penetration. The three cores then recovered were all Cretaceous in age. At the completion of this hole, however, when the drilling pipe was brought aboard the ship, a small amount of sediment adhered to the bit. This was found to contain a coccolith assemblage of the mid-Tertiary Triquetrorhabdulus carinatus Concurrent-range Zone of Bramlette and Wilcoxon. Thus, even though this sediment was bypassed during initial drilling, important additional geologic information was obtained when the bit struck the side of the hole on withdrawal.

The value of coccolith dating to shipboard deep-sea drilling operations has been clearly demonstrated during this Leg 1 operation in the Gulf of Mexico and western Atlantic Ocean.

Kanaya, T., 1957. Eocene diatom assemblages from the Kellogg and "Sidney" Shales, Mt. Diablo area, California. Sci. Rept. Tohoku Univ. Second Ser., Geology. 28, 27.

McIntyre, A., Bé, A. W. H., and Preikstas, R., 1967. Coccoliths and the Pliocene-Pleistocene boundary, In Progress in Oceanography-V. 4, The Quaternary History of the Ocean Basins: London and New York (Pergamon Press), 3.

Noë1, D., 1965. Sur les Coccolithes du Jurassique Européen et d'Afrique du Nord. Centre Natl. Recherche Sci., Paris. 209.

Reinhardt, P., 1966. Zur Taxionomie und Biostratigraphie des fossilen Nannoplanktons aus dem Malm, der Kreide und dem Alttertiär Mittleuropas: Freiberger Forsch. (C196), 5. 
Stover, L. E., 1966. Cretaceous coccoliths and associated nannofossils from France and the Netherlands. Micropalentology. 12 (2), 133.

Stradner, H., 1964. New contributions to Mesozoic stratigraphy by means of nannofossils. World Petroleum Congr., 6th, Frankfurt am Main, Proc. sec. 1, 167.
Stradner, H., and Adamiker, D., 1966. Nannofossilien aus Bohrkernen und ihre elektronenmikroskopische Bearbeitung. Erdöl-Erdgas Zeitschr. 82, 330.

Stradner, H., Adamiker, D., and Maresch, O., 1968. Electron microscope studies on Albian calcareous nannoplankton from the Delft 2 and Leidschendam 1 deepwells, Holland. Koninkl. Ned. Akad. Wetenschap, Afdel, Nat. sec. 1. 24 (4), 107 p. 